Article

\title{
Cyanopeptolins with Trypsin and Chymotrypsin Inhibitory Activity from the Cyanobacterium Nostoc edaphicum CCNP1411
}

\author{
Hanna Mazur-Marzec 1,2,*(1), Anna Fidor ${ }^{1}$, Marta Cegłowska ${ }^{2}$, Ewa Wieczerzak ${ }^{3}$, \\ Magdalena Kropidłowska ${ }^{3}$, Marie Goua ${ }^{4}$ (D), Jenny Macaskill ${ }^{4}$ (i) and Christine Edwards 4 \\ 1 Division of Marine Biotechnology, Faculty of Oceanography and Geography, University of Gdańsk, \\ Marszałka J. Piłsudskiego 46, PL-81378 Gdynia, Poland; anna.fidor77@gmail.com \\ 2 Institute of Oceanology, Polish Academy of Sciences, Powstańców Warszawy 55, PL-81712 Sopot, Poland; \\ mceglowska@iopan.pl \\ 3 Department of Biomedical Chemistry, Faculty of Chemistry, University of Gdańsk, Wita Stwosza 63, \\ PL-80308 Gdańsk, Poland; ewa.wieczerzak@ug.edu.pl (E.W.); \\ magdalena.kropidlowska@phdstud.ug.edu.pl (M.K.) \\ 4 School of Pharmacy and Life Sciences, Robert Gordon University, Aberdeen AB10 7GJ, UK; \\ m.goua@rgu.ac.uk (M.G.); j.s.macaskill@rgu.ac.uk (J.M.); c.edwards@rgu.ac.uk (C.E.) \\ * Correspondence: biohm@ug.edu.pl; Tel.: +48-58-5236621; Fax: 48-58-5236712
}

Received: 5 June 2018; Accepted: 20 June 2018; Published: 26 June 2018

\begin{abstract}
Cyanopeptolins (CPs) are one of the most frequently occurring cyanobacterial peptides, many of which are inhibitors of serine proteases. Some CP variants are also acutely toxic to aquatic organisms, especially small crustaceans. In this study, thirteen CPs, including twelve new variants, were detected in the cyanobacterium Nostoc edaphicum CCNP1411 isolated from the Gulf of Gdańsk (southern Baltic Sea). Structural elucidation was performed by tandem mass spectrometry with verification by NMR for CP962 and CP985. Trypsin and chymotrypsin inhibition assays confirmed the significance of the residue adjacent to 3-amino-6-hydroxy-2-piperidone (Ahp) for the activity of the peptides. Arginine-containing CPs (CPs-Arg $\left.{ }^{2}\right)$ inhibited trypsin at low $\mathrm{IC}_{50}$ values $(0.24-0.26 \mu \mathrm{M})$ and showed mild activity against chymotrypsin $\left(\mathrm{IC}_{50} 3.1-3.8 \mu \mathrm{M}\right)$, while tyrosine-containing CPs $\left(\mathrm{CPs}-\mathrm{Tyr}^{2}\right)$ were selectively and potently active against chymotrypsin $\left(\mathrm{IC}_{50} 0.26 \mu \mathrm{M}\right)$. No degradation of the peptides was observed during the enzyme assays. Neither of the CPs were active against thrombin, elastase or protein phosphatase 1. Two CPs (CP962 and CP985) had no cytotoxic effects on MCF-7 breast cancer cells. Strong and selective activity of the new cyanopeptolin variants makes them potential candidates for the development of drugs against metabolic disorders and other diseases.
\end{abstract}

Keywords: cyanobacteria; Nostoc; cyanopeptolins; protease inhibitors

\section{Introduction}

Cyanobacterial peptides belong to the most interesting group of natural bioactive products. Initially, they were recognized as hepatotoxic and inflammatory agents. In the late 1970s, the therapeutic potential of the compounds attracted the attention of the scientific community [1,2]. Since then, numerous and structurally diverse cyanopeptides have been identified, including potent anticancer agents such as dolastatin 10, cryptophycin 52, largazol, and apratoxin [3-7]. Cyanopeptides have also been recognized as potent inhibitors of key metabolic enzymes, targeting mainly serine proteases and protein phosphatases [7-9]. Among these compounds, cyanopeptolins (CPs), a large family of cyclic depsipeptides (peptidolactones), are commonly produced by different cyanobacterial genera, including Microcystis, Planktothrix, Anabaena and Nostoc. These nonribosomal peptides (NRPs) are composed 
of a six-amino acid ring and a side chain with one or two residues. All CPs are characterized by the presence of 3-amino-6-hydroxy-2-piperidone (Ahp) in position 3 (Figures 1 and 2). In a few CP-type peptides, the occurrence of $O$-methylated Ahp (Amp) in this position has been reported [10-12]. Ahp is also present in other cyclodepsipeptides such as aeruginopeptins, micropeptins, microcystilide, nostopeptins, and oscillapeptins. Position 1 in CP-type peptides is conserved and occupied by L-threonine with $\beta$-hydroxy group linked by an ester bond to carboxy terminus of amino acid in position 6 (i.e., Val, Ile or allo-Ile). Position 2 is most variable and occupied by residues differing in structure and polarity (e.g., Arg, Leu, Gln, Tyr, Phe, MeTyr, $\mathrm{H}_{4} \mathrm{Tyr}, \mathrm{Dhb}$ ) [13]. In position 4, Leu/Ile, Phe or Thr can be found, while in position 5, N-methylated aromatic amino acids, N-MeTyr or MePhe, or their homo-variants are usually present. In some CPs, Tyr or N-MeTyr were modified by chlorination [14]. The side chain is attached via the amino group on Thr. Usually, two major types of side chains were reported: with 1-2 amino acid residues (e.g., Asp, Glu) and aliphatic fatty acid of variable length or with glyceric acid directly linked to Thr or to an amino acid side chain [15-17]. Glyceric acid can be modified by sulfation or/and O-methylation [11,18]. In the side chain of aeruginopeptins, micropeptins or microcystilide, a hydroxyphenyl lactic acid (Hpla) was reported [19-21].

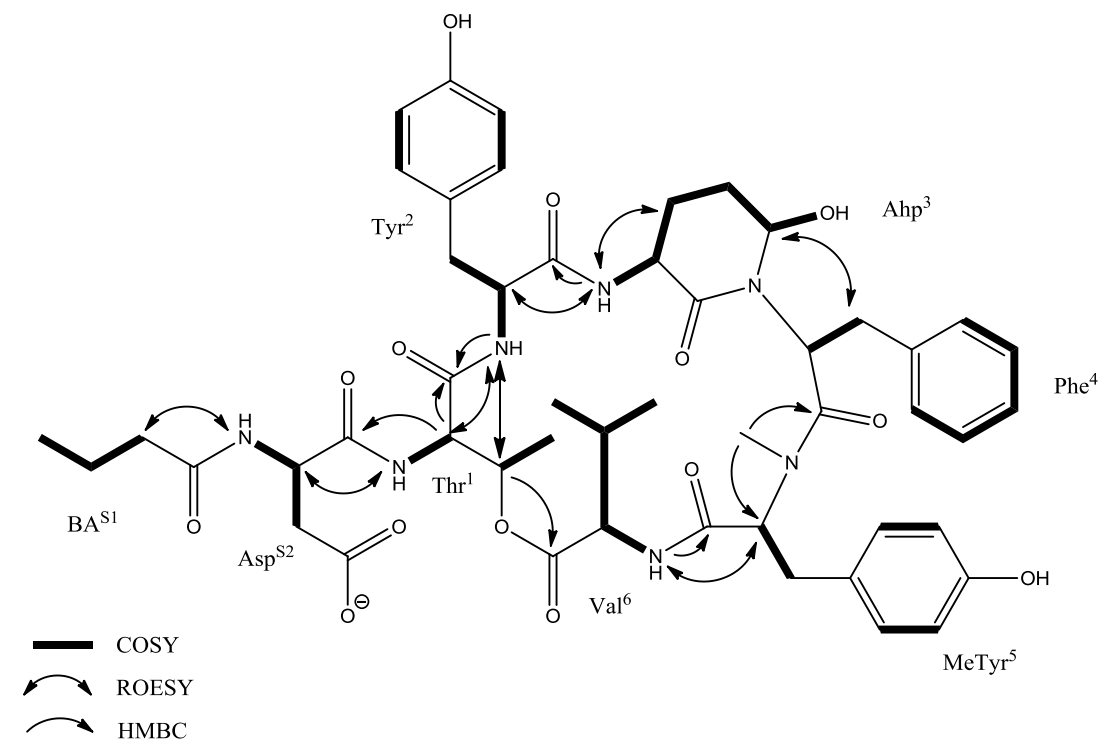

Figure 1. COSY, ROESY, and HMBC correlations in cyanopeptolin CP985.

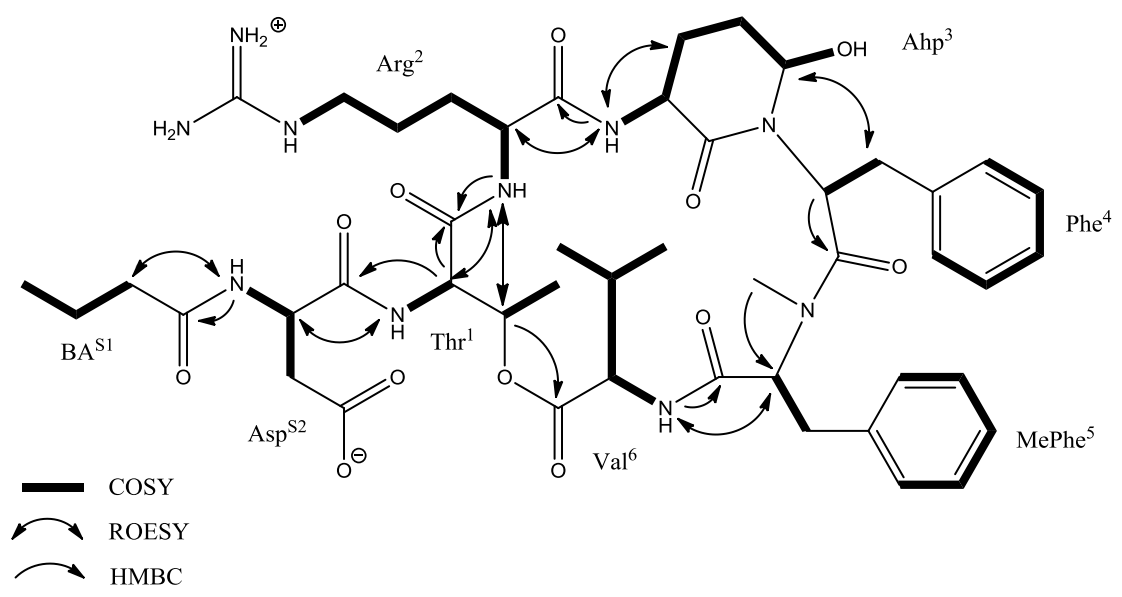

Figure 2. Key COSY, ROESY, and HMBC correlations in cyanopeptolin CP962. 
Cyanopeptolins, like other nonribosomal peptides, are synthesized on large multi-enzyme complexes with modular structure. The general organization of the gene clusters encoding the enzymes in different cyanobacteria is similar, however, some differences in the specificity of adenylation domains and in the presence of tailoring domains exist [22-24]. In the CP gene cluster from Microcystis and Anabaena, a halogenase gene was present [23,24], whereas in Planktothrix a glyceric acid-activating domain and sulfotransferase domain occurred [22]. The modifications in gene clusters and differences in substrate specificity of adenylation domains result in intra- and interspecies diversity of $\mathrm{CP}$ structures.

The majority of CPs showed inhibitory activity against serine proteases, such as trypsin, chymotrypsin, thrombin, and elastase (e.g., [12,25-30]). Cyanopeptolins with one (CP S) or two sulphate groups (CP SS) also inhibited plasmin [18]. The activity of the peptides was found to be determined by the residue in position 2 , however, the significance of other structural elements was also reported [12]. In ichthyopeptins, CP analogues with 2-hydroxy-3-(4'-hydroxyphenyl)lactic acid (PAA) in the side chain, strong antiviral activity against influenza A virus was observed [31]. Tests on small crustaceans revealed the harmful effects of Ahp-containing cyclic depsipeptides [16,32,33]. For CP SS, the toxicity against Daphnia magna was even higher than for microcystin-LR [10], the most widely studied cyanobacterial toxin.

In cyanobacterial strains from the Nostoc genus, typical CP variants produced by Microcystis have not been reported. However, several other CP-type structures, namely nostopeptins, insulapeptolides, and nostocyclins were identified (Table 1) [34-38]. Nostopeptin A and B from N. minutum NIES-26, with 3-hydroxy-4-methylproline ( $\mathrm{Hmp}$ ) in position 1, showed inhibitory activity against elastase and chymotrypsin, but were inactive against papain, trypsin, thrombin, and plasmin [35]. Insulapeptolides A-D from $N$. insulare are characterized by the presence of Hmp in position 1 and citrulline (Cit) in the side chain. Extracts containing these peptides potently and selectively inhibited human leukocyte elastase (HLE) [38]. Nostocyclin from Nostoc sp. DUN901 has D-Hpla in the side chain and two homoserine residues (Hse): one in a ring part and one in a side chain of the molecule [34]. The peptide was not toxic in mouse bioassay, but showed weak activity against protein phosphatases [34,39].

Among cyanobacterial strains from the same species, significant differences in the peptide profiles are frequently reported. In our study, the structures of CPs produced by N. edaphicum CCNP1411 isolated from coastal waters of the Gulf of Gdańsk, southern Baltic Sea, were elucidated. In total, thirteen $\mathrm{CP}$ variants were identified. They represent structures typical of CPs from Microcystis, but different from CP-type peptides previously found in other Nostoc strains. The biological activity of the peptides against serine proteases, protein phosphatase 1, and MCF-7 breast cancer cells were assessed. 
Table 1. Cyanopeptolin-type peptides identified in cyanobacteria from Nostoc genus.

\begin{tabular}{|c|c|c|c|c|}
\hline Molecular Mass & Peptide Name & Structure & Enzyme Inhibition & References \\
\hline 921 & Nostopeptin BN920 & {$\left[\mathrm{Thr}+\mathrm{Leu}+\mathrm{Ahp}^{1}+\mathrm{Phe}+\mathrm{MeTyr}+\mathrm{Val}\right] \mathrm{Gln}+\mathrm{Ac}{ }^{2}$} & $\begin{array}{l}\text { Chymotrypsin } \\
\left(\mathrm{IC}_{50} 0.11 \mu \mathrm{M}\right)\end{array}$ & [36] \\
\hline 926 & Nostopeptin B & {$\left[\mathrm{Hmp}^{3}+\mathrm{Leu}+\mathrm{Ahp}+\mathrm{Ile}+\mathrm{MeTyr}+\mathrm{Ile}\right] \mathrm{Gln}+\mathrm{Ac}$} & $\begin{array}{c}\text { Elastase } \\
\left(\mathrm{IC}_{50} 11.0 \mu \mathrm{g} / \mathrm{mL}\right) \\
\text { Chymotrypsin } \\
\left(\mathrm{IC}_{50} 1.6 \mu \mathrm{g} / \mathrm{mL}\right)\end{array}$ & [35] \\
\hline 937 & Nostopeptin A & {$[\mathrm{Hmp}+\mathrm{Leu}+\mathrm{Ahp}+\mathrm{Ile}+\mathrm{MeTyr}+\mathrm{Ile}] \mathrm{Gln}+\mathrm{BA}^{4}$} & $\begin{array}{c}\text { Elastase } \\
\left(\mathrm{IC}_{50} 1.3 \mu \mathrm{g} / \mathrm{mL}\right) \\
\text { Chymotrypsin } \\
\left(\mathrm{IC}_{50} 1.4 \mu \mathrm{g} / \mathrm{mL}\right)\end{array}$ & [35] \\
\hline 942 & Insulapeptolide A & {$[\mathrm{Hmp}+\mathrm{Leu}+\mathrm{Ahp}+\mathrm{Ile}+\mathrm{MeTyr}+\mathrm{Val}] \mathrm{Cit}^{5}+\mathrm{Ac}$} & $\operatorname{HLE}^{10}\left(\mathrm{IC}_{50} 0.14 \mu \mathrm{M}\right) *$ & \multirow{8}{*}{ [38] } \\
\hline 956 & Insulapeptolide B & {$[$ Hmp+Leu+Ahp+Leu+MeTyr+Ile]Cit+Ac } & $\operatorname{HLE}\left(\mathrm{IC}_{50} 0.10 \mu \mathrm{M}\right) *$ & \\
\hline 956 & Insulapeptolide C & {$\left[\mathrm{Hmp}+\mathrm{Leu}+\mathrm{Ahp}+\mathrm{Ile}+\mathrm{diMeTyr}^{6}+\mathrm{Val}\right] \mathrm{Cit}+\mathrm{Ac}$} & $\operatorname{HLE}\left(\mathrm{IC}_{50} 0.090 \mu \mathrm{M}\right) *$ & \\
\hline 970 & Insulapeptolide D & {$[\mathrm{Hmp}+\mathrm{Leu}+\mathrm{Ahp}+\mathrm{Ile}+\mathrm{diMeTyr}+\mathrm{Ile}] \mathrm{Cit}+\mathrm{Ac}$} & $\operatorname{HLE}\left(\mathrm{IC}_{50} 0.085 \mu \mathrm{M}\right) *$ & \\
\hline 991 & Insulapeptolide G & {$\left[\mathrm{Thr}+\mathrm{Hph}^{7}+\mathrm{Ahp}+\mathrm{Thr}+\mathrm{MePhe}+\right.$ Val]Ser+Pro+BA } & $\operatorname{HLE}\left(\mathrm{IC}_{50} 3.5 \mu \mathrm{M}\right) *$ & \\
\hline 1005 & Insulapeptolide $\mathrm{H}$ & [Thr+Hph+Ahp+Thr+MeTyr+Ile]Ser+Pro+BA & HLE $\left(\mathrm{IC}_{50} 2.7 \mu \mathrm{M}\right) *$ & \\
\hline 1007 & Insulapeptolide F & {$[\mathrm{Thr}+\mathrm{Hph}+\mathrm{Ahp}+\mathrm{Thr}+\mathrm{MeTyr}+\mathrm{Val}] \mathrm{Ser}+\mathrm{Pro}+\mathrm{BA}$} & $\operatorname{HLE}\left(\mathrm{IC}_{50} 1.6 \mu \mathrm{M}\right) *$ & \\
\hline 1021 & Insulapeptolide E & [Thr+Hph+Ahp+Thr+MeTyr+Ile]Ser+Pro+BA & $\operatorname{HLE}\left(\mathrm{IC}_{50} 3.2 \mu \mathrm{M}\right)$ * & \\
\hline 1116 & Nostocyclin & {$\left[\mathrm{Thr}+\mathrm{Hse}^{8}+\right.$ Ahp $\left.+\mathrm{Phe}+\mathrm{MeTyr}+\mathrm{Val}\right] \mathrm{Hse}+\mathrm{Ile}+\mathrm{Hpla}^{9}$} & PP1 $\left(\mathrm{IC}_{50} 64.0 \mu \mathrm{M}\right)$ & [34] \\
\hline
\end{tabular}

* activity of extracts; ${ }^{1}$ Ahp 3-amino-6-hydroxy-2-piperidone; ${ }^{2}$ Ac acetic acid; ${ }^{3} \mathrm{Hmp}$ 3-hydroxy-4-methyl-proline; ${ }^{4}$ BA butanoic acid; ${ }^{5}$ Cit citrulline; ${ }^{6}$ diMeTyr $\mathrm{N}, \mathrm{O}$-dimethyltyrosine;

${ }^{7}$ Hph homophenylalanine; ${ }^{8}$ Hse homoserine; ${ }^{9}$ Hpla p-hydroxyphenyllactic acid; ${ }^{10}$ HLE human leukocyte elastase. 


\section{Results}

\subsection{LC-MS/MS Analysis of Cyanopeptolins}

Fractionation of N. edaphicum CCNP1411 crude extract (Figure S1) resulted in isolation of thirteen CPs. Structures were identified using a quadrupole/time of flight mass spectrometer and a triple quadrupole/linear ion trap mass spectrometer (Table 2). Structural elucidation of the peptides was based on fragmentation spectra with diagnostic ions, including immonium ions and a series of other fragment ions associated with specific residues. Depending on the residue in position 2, two types of spectra were obtained. $\mathrm{Arg}^{2}$-containing $\mathrm{CPs}\left(\mathrm{CPs}-\mathrm{Arg}^{2}\right)$, gave pseudomolecular ions $[\mathrm{M}+\mathrm{H}]^{+}$at $\mathrm{m} / z$ 1049, 1021, 1019, 1007, 979, 993, 991, and 963. The Tyr $^{2}$-containing peptides $\left(C P s-T y r^{2}\right.$ ) were detected as dehydrated protonated molecules $\left[\mathrm{M}+\mathrm{H}-\mathrm{H}_{2} \mathrm{O}\right]^{+}$at $m / z 1010,996,982,968$, and 952, and the Tyr-immonium ion $(m / z 136)$ was always present in their spectra. The putative planar structures of CPs detected in N. edaphicum CCNP1411 and their fragmentation spectra are presented in Figures 1-4 and in supplementary information (Figures S2-S12). Amino acids at positions 1, 3, 4, 6, and 7 were found to be conserved and occupied by $\mathrm{Thr}^{1}, \mathrm{Ahp}^{3}, \mathrm{Phe}^{4}, \mathrm{Val}^{6}$, and $\mathrm{Asp}^{7}$, respectively. The ion peak corresponding to the longest sequence of residues common to all $\mathrm{CP}$ variants was observed in the spectra at $m / z 297\left[\text { Asp }+\mathrm{Thr}+\mathrm{Val}+\mathrm{H}-\mathrm{H}_{2} \mathrm{O}\right]^{+}$or $/$and at $m / z 269$ [Asp $+\mathrm{Thr}+\mathrm{Val}+\mathrm{H}-\mathrm{H}_{2} \mathrm{O}$ $-\mathrm{CO}^{+}$. The presence of butanoic acid (BA), hexanoic acid (HA), or octanoic acid (OA) in the side chain was mainly indicated by ion peaks formed by the cleavage of the corresponding fatty acid group (FA) and the exocyclic aspartic acid (Figures 3 and 4; Figures S2-S12). As this cleavage produced a stable cyclic part of the molecule, the ions $\left[\mathrm{M}+\mathrm{H}-\left(\mathrm{H}_{2} \mathrm{O}\right)-(\mathrm{FA}+\mathrm{Asp})\right]^{+}$usually belonged to the most abundant ones. The residue in position 5 (i.e., $\mathrm{N}$-MePhe, $\mathrm{N}$-MeTyr or $\mathrm{N}$-MeHty) was identified based on immonium ion peaks at $m / z$ 134, 150 or 164, respectively, and peaks at $m / z$ 404, 420, and 434 corresponding to $\left[\mathrm{Ahp}+\mathrm{Phe}+(\mathrm{MePhe} / \mathrm{MeTyr} / \mathrm{MeHty})+\mathrm{H}-\mathrm{H}_{2} \mathrm{O}\right]^{+\cdot}$ Ion peak at $m / z 120$, as well as peaks at $243\left[\mathrm{Ahp}+\mathrm{Phe}+\mathrm{H}-\mathrm{H}_{2} \mathrm{O}\right]^{+}$and $215\left[\mathrm{Ahp}+\mathrm{Phe}+\mathrm{H}-\mathrm{H}_{2} \mathrm{O}-\mathrm{CO}\right]^{+}$confirmed the presence of Phe in position 4.
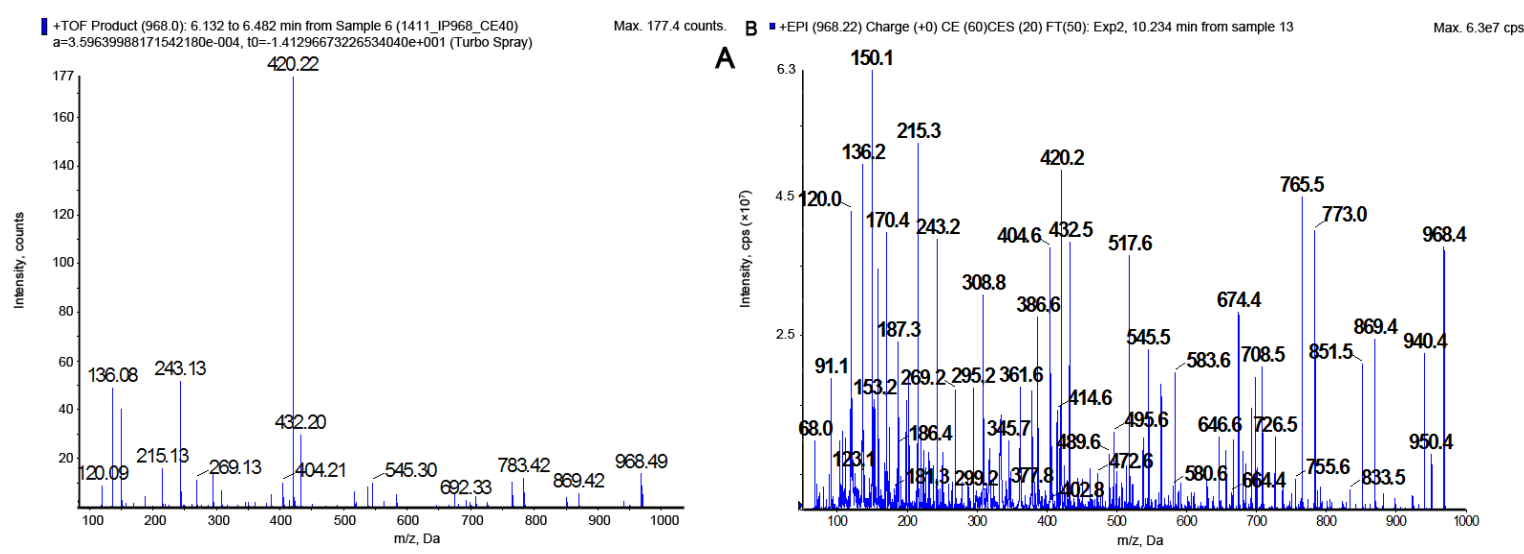

Figure 3. The product ion mass spectra of CP985 [Thr+Tyr+Ahp+Phe+MeTyr+Va]Asp+BA with precursor ion $\left[\mathrm{M}+\mathrm{H}-\mathrm{H}_{2} \mathrm{O}\right]$ at $m / z$ 968. The spectra were recorded with application of a hybride quadrupole/time-of-flight mass spectrometer (QTOF) (A) and a hybride triple quadrupole/linear ion trap mass spectrometer (QTRAP) (B). The mass signals were assigned to the following fragments: $950\left[\mathrm{M}+\mathrm{H}-2 \mathrm{H}_{2} \mathrm{O}\right]^{+}, 869\left[\mathrm{M}+\mathrm{H}-\mathrm{Val}-\mathrm{H}_{2} \mathrm{O}\right]^{+}, 851\left[\mathrm{M}+\mathrm{H}-\mathrm{Val}-2 \mathrm{H}_{2} \mathrm{O}\right]^{+}, 773[\mathrm{M}+2 \mathrm{H}-$ $(\mathrm{BA}+\mathrm{Asp})-\mathrm{CO}^{+}, 765\left[\mathrm{M}+2 \mathrm{H}-(\mathrm{BA}+\mathrm{Asp})-2 \mathrm{H}_{2} \mathrm{O}\right]^{+}, 692\left[\mathrm{M}+\mathrm{H}-(\mathrm{Val}+\mathrm{MeTyr})-\mathrm{H}_{2} \mathrm{O}\right]^{+}, 674$ $\left[\mathrm{M}+\mathrm{H}-(\mathrm{Val}+\mathrm{MeTyr})-2 \mathrm{H}_{2} \mathrm{O}\right]^{+}, 646\left[\mathrm{M}+\mathrm{H}-(\mathrm{Val}+\mathrm{MeTyr})-2 \mathrm{H}_{2} \mathrm{O}-\mathrm{CO}^{+}, 432[\mathrm{M}+\mathrm{H}-(\mathrm{Val}+\right.$ MeTyr + Phe + Ahp $\left.)-\mathrm{H}_{2} \mathrm{O}\right]^{+}, 420\left[\mathrm{Ahp}+\mathrm{Phe}+\mathrm{MeTyr}+\mathrm{H}-\mathrm{H}_{2} \mathrm{O}\right]^{+}, 404[\mathrm{M}+\mathrm{H}-(\mathrm{Val}+\mathrm{MeTyr}+$ $\left.\mathrm{Phe}+\mathrm{Ahp})-\mathrm{H}_{2} \mathrm{O}-\mathrm{CO}\right]^{+}, 386[\mathrm{BA}+\mathrm{Asp}+\mathrm{Thr}+\mathrm{Val}+\mathrm{H}]^{+}, 308[\mathrm{Phe}(-\mathrm{N})+\mathrm{MeTyr}+\mathrm{H}]^{+}, 297[$ Asp $+\mathrm{Thr}+\mathrm{Val}+\mathrm{H}-\mathrm{H}_{2} \mathrm{O}-\mathrm{CO}^{+}, 243\left[\mathrm{Ahp}+\mathrm{Phe}+\mathrm{H}-\mathrm{H}_{2} \mathrm{O}\right]^{+}, 215\left[\mathrm{Ahp}+\mathrm{Phe}+\mathrm{H}-\mathrm{H}_{2} \mathrm{O}-\mathrm{CO}\right]^{+}$, 150 MeTyr immonium ion, 136 Tyr immonium ion, 120 Phe immonium ion. 
Table 2. Cyanopeptolins identified in Nostoc edaphicum CCNP 1411. The activities of the peptides were assessed in serine proteases (trypsin, chymotrypsin, elastase, and thrombin) and protein phosphatases 1 (PP 1) inhibition assays (- not active; ${ }^{*}{ }^{* *}$ small/medium activity; $m / z$ of precursor ions: $[\mathrm{M}+\mathrm{H}]^{+}$for $\mathrm{CPs}-\mathrm{Arg}{ }^{2}$ and $[\mathrm{M}+$ $\left.\mathrm{H}-\mathrm{H}_{2} \mathrm{O}\right]^{+}$for CPs-Tyr ${ }^{2}$.

\begin{tabular}{|c|c|c|c|c|c|c|c|}
\hline \multirow[b]{2}{*}{ Cyanopeptolin CP } & \multirow[b]{2}{*}{$m / z$} & \multirow[b]{2}{*}{ Structure } & \multicolumn{5}{|c|}{ Enzyme Inhibition $\left(\mathrm{IC}_{50}[\mu \mathrm{M}]\right)$} \\
\hline & & & Chymotrypsin & Trypsin & Elastase & Thrombin & $\begin{array}{c}\text { Protein } \\
\text { Phosphatase } 1\end{array}$ \\
\hline СР 1048 & 1049 & {$[\mathrm{Thr}+\mathrm{Arg}+\mathrm{Ahp}+\mathrm{Phe}+\mathrm{MeHty}+\mathrm{Val}] \mathrm{Asp}+\mathrm{OA}$} & * & $* *$ & - & - & - \\
\hline CP 1020 & 1021 & {$[\mathrm{Thr}+\mathrm{Arg}+\mathrm{Ahp}+\mathrm{Phe}+\mathrm{MeHty}+\mathrm{Val}$ Asp $+\mathrm{HA}$} & 3.1 & 0.25 & - & - & - \\
\hline CP 1018 & 1019 & {$[\mathrm{Thr}+\mathrm{Arg}+\mathrm{Ahp}+\mathrm{Phe}+\mathrm{MePhe}+\mathrm{Val}] \mathrm{Asp}+\mathrm{OA}$} & - & 0.24 & - & - & - \\
\hline CP 1006 & 1007 & {$[$ Thr + Arg + Ahp + Phe+MeTyr + Val $]$ Asp + HA } & * & $* *$ & - & - & - \\
\hline СР 992 & 993 & {$[\mathrm{Thr}+\mathrm{Arg}+\mathrm{Ahp}+\mathrm{Phe}+\mathrm{MeHty}+\mathrm{Val}] \mathrm{Asp}+\mathrm{BA}$} & 3.5 & 0.24 & - & - & - \\
\hline СР 990 & 991 & {$[\mathrm{Thr}+\mathrm{Arg}+\mathrm{Ahp}+\mathrm{Phe}+\mathrm{MePhe}+\mathrm{Val}] \mathrm{Asp}+\mathrm{HA}$} & - & $* *$ & - & - & - \\
\hline СР 978 & 979 & {$[\mathrm{Th} r+\mathrm{Arg}+\mathrm{Ahp}+\mathrm{Phe}+\mathrm{MeTyr}+\mathrm{Val}] \mathrm{Asp}+\mathrm{BA}$} & 3.8 & 0.26 & - & - & - \\
\hline CP 962 & 963 & {$[$ Thr+Arg + Ahp + Phe + MePhe+Val]Asp + BA } & - & $* *$ & - & - & - \\
\hline CP 1027 & 1010 & {$[\mathrm{Thr}+\mathrm{Ty} r+\mathrm{Ahp}+\mathrm{Phe}+\mathrm{MeHty}+\mathrm{Val}]$ Asp $+\mathrm{HA}$} & 0.26 & - & - & - & - \\
\hline СР 1013 & 996 & {$[\mathrm{Thr}+\mathrm{Tyr}+\mathrm{Ahp}+\mathrm{Phe}+\mathrm{MeTyr}+\mathrm{Val}] \mathrm{Asp}+\mathrm{HA}$} & $* *$ & - & - & - & - \\
\hline СР 999 & 982 & {$[\mathrm{Thr}+\mathrm{Tyr}+\mathrm{Ahp}+\mathrm{Phe}+\mathrm{MeHty}+\mathrm{Val}] \mathrm{Asp}+\mathrm{BA}$} & ** & - & - & - & - \\
\hline СР 985 & 968 & {$[\mathrm{Thr}+\mathrm{Tyr}+\mathrm{Ahp}+\mathrm{Phe}+\mathrm{MeTyr}+\mathrm{Val}] \mathrm{Asp}+\mathrm{BA}$} & 0.26 & - & - & - & - \\
\hline СР 969 & 952 & {$[\mathrm{Thr}+\mathrm{Tyr}+\mathrm{Ahp}+\mathrm{Phe}+\mathrm{MePhe}+\mathrm{Val}] \mathrm{Asp}+\mathrm{BA}$} & $* *$ & - & - & - & - \\
\hline
\end{tabular}



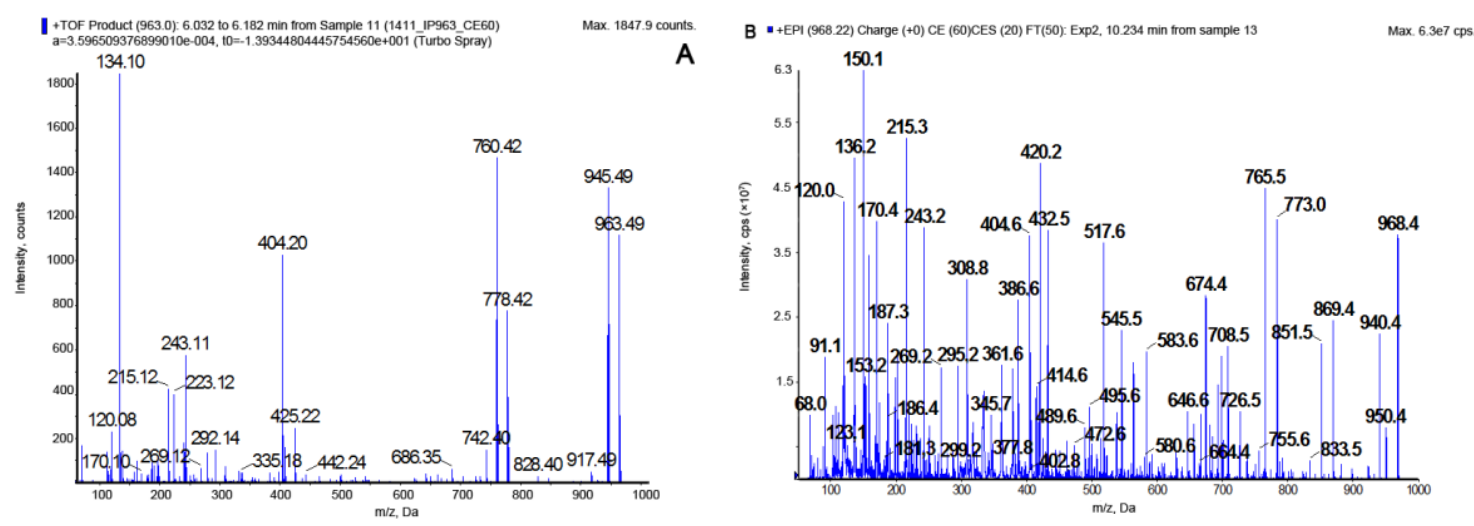

Figure 4. The product ion mass spectra of CP962 [Thr+Arg+Ahp+Phe+MePhe+Val]Asp+BA with precursor ion $[\mathrm{M}+\mathrm{H}]+$ at $m / z$ 963. The spectra were recorded with application of a hybride quadrupole/time-of-flight mass spectrometer (QTOF) (A) and a hybride triple quadrupole/linear ion trap mass spectrometer (QTRAP) (B). The mass signals were assigned to the following fragments: $945\left[\mathrm{M}+\mathrm{H}-\mathrm{H}_{2} \mathrm{O}\right]^{+}, 917\left[\mathrm{M}+\mathrm{H}-\mathrm{H}_{2} \mathrm{O}-\mathrm{CO}^{+}, 846\left[\mathrm{M}+\mathrm{H}-\mathrm{Val}-\mathrm{H}_{2} \mathrm{O}\right]^{+}, 828[\mathrm{M}+\mathrm{H}-\mathrm{Val}-\right.$ $\left.2 \mathrm{H}_{2} \mathrm{O}\right]^{+}, 778[\mathrm{M}+2 \mathrm{H}-(\mathrm{BA}+\mathrm{Asp})]^{+}, 760\left[\mathrm{M}+2 \mathrm{H}-(\mathrm{BA}+\mathrm{Asp})-\mathrm{H}_{2} \mathrm{O}\right]^{+}, 742[\mathrm{M}+2 \mathrm{H}-(\mathrm{BA}+\mathrm{Asp})$ $\left.-2 \mathrm{H}_{2} \mathrm{O}\right]^{+}, 685\left[\mathrm{M}+\mathrm{H}-(\mathrm{Val}+\mathrm{MePhe})-\mathrm{H}_{2} \mathrm{O}\right]^{+}, 425\left[\mathrm{BA}+\mathrm{Asp}+\mathrm{Thr}+\mathrm{Arg}+\mathrm{H}-\mathrm{H}_{2} \mathrm{O}\right]^{+}, 404[\mathrm{Ahp}$ $\left.+\mathrm{Phe}+\mathrm{MePhe}+\mathrm{H}-\mathrm{H}_{2} \mathrm{O}\right]^{+}, 297\left[\mathrm{Asp}+\mathrm{Thr}+\mathrm{Val}+\mathrm{H}-\mathrm{H}_{2} \mathrm{O}\right]^{+}, 243\left[\mathrm{Ahp}+\mathrm{Phe}+\mathrm{H}-\mathrm{H}_{2} \mathrm{O}\right]^{+}, 215$ $\left[\mathrm{Ahp}+\mathrm{Phe}+\mathrm{H}-\mathrm{H}_{2} \mathrm{O}-\mathrm{CO}\right]^{+}, 134 \mathrm{MePhe}$ immonium ion, 120 Phe immonium ion, 70-Arg.

\subsection{NMR Analysis}

In order to confirm the structures, two CPs (i.e., CP962 and CP985) were purified in sufficient quantities for NMR spectroscopy. For both compounds the ${ }^{1} \mathrm{H}-\mathrm{NMR}$ spectra displayed the typical pattern of a peptide (i.e., doublet amide protons $\left(\delta_{\mathrm{H}} 6.95-8.51 \mathrm{ppm}\right)$ and a single amide methyl group $\left(\delta_{\mathrm{H}} 2.71 \mathrm{ppm}\right.$ for CP985 and $2.84 \mathrm{ppm}$ for CP962). The COSY, TOCSY, and HMBC experiments allowed assignment of NMR spin systems to Asp, Thr, Tyr, Ahp (3-amino-6-hydroxypiperid-2-one), Phe, MeTyr ( $N$-methyl tyrosine), Val, and butanoic acid (BA) in the case of cyanopeptolin CP985 (Table 3, Figures $\mathrm{S} 13-\mathrm{S18b}$ ). The presence of aromatic amino acid residues was recognized by the signals occurring in the aromatic region of the spectrum $\left(\delta_{\mathrm{H}} 6.5-7.5 \mathrm{ppm}\right)$. The $\mathrm{AA}^{\prime} \mathrm{BB}^{\prime}$ spin systems between two sets of tyrosine (Tyr-H2 ${ }^{\prime} / 6^{\prime}$ and Tyr- $\mathrm{H} 3^{\prime} / 5^{\prime}, J_{\mathrm{H}, \mathrm{H}}=8.4 \mathrm{~Hz}$ ) and $\mathrm{N}$-methyl tyrosine aromatic protons (MeTyr-H2 $2^{\prime} / 6^{\prime}$ and MeTyr-H3 $3^{\prime} / 5^{\prime}, J_{\mathrm{H}, \mathrm{H}}=8.4 \mathrm{~Hz}$ ) indicated the presence of two para-di-substituted phenyl rings. The ${ }^{1} \mathrm{H}-{ }^{13} \mathrm{C}$ long range correlation from $\mathrm{MeTyr}-\mathrm{NH}-\mathrm{CH}_{3}$ group $\left(\delta_{\mathrm{H}} 2.71 \mathrm{ppm}\right)$ to the MeTyr-C2 atom $\left(\delta_{C} 61.3 \mathrm{ppm}\right)$ revealed the presence of $N$-methyl tyrosine residue. Phenylalanine was found to be the third aromatic amino acid residue based on the COSY interaction between Phe- $\mathrm{H} 2^{\prime} / 6^{\prime}$, Phe- $\mathrm{H}^{\prime} / 5^{\prime}$, and Phe- $\mathrm{H} 4^{\prime}$, and the HMBC correlation from two diastereotopic methylene protons Phe- $3 \mathrm{a}\left(\delta_{\mathrm{H}} 2.88 \mathrm{ppm}\right)$ and Phe-3b $\left(\delta_{\mathrm{H}} 1.81 \mathrm{ppm}\right)$ to the aromatic Phe-C2 $2^{\prime} / 6^{\prime}$ carbons. The presence of Asp, Val, and Thr was confirmed by their characteristic spin systems in the COSY spectrum (Figure S17b). The macrocyclic ring closure between threonine and valine was verified by HMBC correlation between Thr-H3 $\left(\delta_{\mathrm{H}} 5.36 \mathrm{ppm}\right)$ and Val-C1 $\left(\delta_{\mathrm{C}} 172.4 \mathrm{ppm}\right)$ (Figure S15b). The presence of Ahp residue was detected by the characteristic signal of the $\mathrm{OH}$ proton $\left(\delta_{\mathrm{H}} 5.99 \mathrm{ppm}\right)$ and a broad singlet $\left(\delta_{\mathrm{H}} 5.06 \mathrm{ppm}\right)$ derived from $\mathrm{H} 5$ proton (Figure S13). The HMBC correlations from Ahp-C1 to Ahp-H5 and Ahp-H2 confirmed the cyclic nature of this residue.

The COSY, TOCSY, and HMBC data allowed identification of amino acid residues in CP CP962 as Asp, Thr, Arg, Ahp, Phe, MePhe ( $N$-methyl phenylalanine), Val, and BA, analogously to CP985 (Table 4, Figures S19-S24b). Two aromatic residues were found: phenylalanine and N-methyl phenylalanine. The occurrence of $N$-methyl group was established by the ${ }^{1} \mathrm{H}^{13} \mathrm{C}$ long range correlation from MePhe-NH- $\mathrm{CH}_{3}$ group $\left(\delta_{\mathrm{H}} 2.84 \mathrm{ppm}\right)$ to the MePhe-C2 atom. The typical ${ }^{13} \mathrm{C}$ chemical shift of the guanidine quaternary carbon $\left(\delta_{C} 158.7 \mathrm{ppm}\right)$ indicated the presence of Arg whose complete spin system was assigned based on TOCSY and COSY interactions (Figure S23b). The diagnostic 
regions of the TOCSY, ROESY and HMBC spectra of both cyanopeptolins analyzed are presented in corresponding figures in Supplementary.

Table 3. NMR Spectroscopic data $\left(700 \mathrm{MHz}\right.$, DMSO- $\left.d_{6}\right)$ for cyanopeptolin CP985 $[$ Thr+Tyr+Ahp+Phe+MeTyr+Val]Asp+BA.

\begin{tabular}{|c|c|c|c|c|c|}
\hline Unit & Position & $\delta_{C}$ & $\delta_{\mathrm{H}}(J$ in $\mathrm{Hz})$ & ROESY & HМBC $^{a}$ \\
\hline BA & $\begin{array}{l}1 \\
2 \\
3 \\
4 \\
\end{array}$ & $\begin{array}{l}172.9, \mathrm{C} \\
37.7, \mathrm{CH}_{2} \\
19.2, \mathrm{CH}_{2} \\
14.2, \mathrm{CH}_{3} \\
\end{array}$ & $\begin{array}{c}2.11, \mathrm{~m} \\
1.56, \mathrm{~m} \\
0.89, \mathrm{t}(7.2,7.2)\end{array}$ & Asp-NH & $\begin{array}{c}\text { BA-1, BA-3, BA-4 } \\
\text { BA-1, BA-2, BA-4 } \\
\text { BA-2 }\end{array}$ \\
\hline Asp & $\begin{array}{c}1 \\
2 \\
3 \mathrm{a} \\
3 \mathrm{~b} \\
4 \\
\mathrm{NH}\end{array}$ & $\begin{array}{c}171.7, \mathrm{C} \\
49.9, \mathrm{CH} \\
36.1, \mathrm{CH}_{2} \\
172.4, \mathrm{C}\end{array}$ & $\begin{array}{l}4.58, \mathrm{dd}(8.0,5.0) \\
2.65, \mathrm{~m} \\
2.46, \mathrm{~m} \\
8.26, \mathrm{~m}\end{array}$ & Thr-NH & Asp-4 \\
\hline Thr ${ }^{1}$ & $\begin{array}{c}1 \\
2 \\
3 \\
4 \\
\mathrm{NH}\end{array}$ & $\begin{array}{c}168.9, \mathrm{C} \\
54.7, \mathrm{CH} \\
72.6, \mathrm{CH} \\
18.0, \mathrm{CH}_{3}\end{array}$ & $\begin{array}{c}4.52, \mathrm{~d}(10.0) \\
5.36, \mathrm{q}(6.8,6.9,6.8) \\
1.16, \mathrm{~d}(7.2) \\
7.52, \mathrm{~d}(9.3)\end{array}$ & $\begin{array}{c}\text { Tyr-NH } \\
\text { Tyr-NH } \\
\text { Asp-2 }\end{array}$ & $\begin{array}{l}\text { Thr-1, Asp-1 } \\
\text { Val-1 } \\
\text { Thr-2, Thr-3 }\end{array}$ \\
\hline $\mathrm{Tyr}^{2}$ & $\begin{array}{c}1 \\
2 \\
3 \mathrm{a} \\
3 \mathrm{~b} \\
1^{\prime} \\
2^{\prime} / 6^{\prime} \\
3^{\prime} / 5^{\prime} \\
4^{\prime} \\
\mathrm{NH}\end{array}$ & $\begin{array}{c}169.9, \mathrm{C} \\
54.2, \mathrm{CH} \\
35.5, \mathrm{CH}_{2} \\
128.5, \mathrm{C} \\
130.1, \mathrm{CH} \\
115.5, \mathrm{CH} \\
156.1, \mathrm{C}\end{array}$ & $\begin{array}{c}4.31, \mathrm{~m} \\
3.11, \mathrm{~m} \\
2.55, \mathrm{~m} \\
6.89, \mathrm{~d}(8.4) \\
6.58, \mathrm{~d}(8.4) \\
8.46, \mathrm{~d}(8.8)\end{array}$ & $\begin{array}{c}\text { Ahp-NH } \\
\text { Thr-2, Thr-3 }\end{array}$ & $\begin{array}{c}\text { Tyr-2, Tyr-1' } \\
\text { Tyr-1' } \\
\text { Tyr-4 } \\
\text { Thr-1 }\end{array}$ \\
\hline$A h p^{3}$ & $\begin{array}{c}1 \\
2 \\
3 \\
4 \\
5 \\
\mathrm{NH} \\
\mathrm{OH}\end{array}$ & $\begin{array}{c}169.0, \mathrm{C} \\
49.4, \mathrm{CH} \\
22.0, \mathrm{CH}_{2} \\
21.9, \mathrm{CH}_{2} \\
74.1, \mathrm{CH}\end{array}$ & $\begin{array}{c}3.62, \mathrm{~m} \\
2.41, \mathrm{~m} \\
1.64, \mathrm{~m} \\
5.06, \mathrm{brs} \\
7.06, \mathrm{~d}(8.8) \\
5.99, \mathrm{~d}(3.1)\end{array}$ & $\begin{array}{l}\text { Ahp-NH } \\
\text { Phe-3a, } \\
\text { Phe-3b } \\
\text { Tyr-2, } \\
\text { Ahp-3 }\end{array}$ & $\begin{array}{c}\text { Ahp-1, Ahp-3 } \\
\text { Ahp-2 } \\
\text { Ahp-1 } \\
\text { Tyr-1 }\end{array}$ \\
\hline Phe $^{4}$ & $\begin{array}{c}1 \\
2 \\
3 \mathrm{a} \\
3 \mathrm{~b} \\
1^{\prime} \\
2^{\prime} / 6^{\prime} \\
3^{\prime} / 5^{\prime} \\
4^{\prime}\end{array}$ & $\begin{array}{c}170.8, \mathrm{C} \\
50.7, \mathrm{CH} \\
35.8, \mathrm{CH}_{2} \\
137.2, \mathrm{C} \\
129.9, \mathrm{CH} \\
128.2, \mathrm{CH} \\
126.7, \mathrm{CH}\end{array}$ & $\begin{array}{c}4.76, \mathrm{dd}(7.1,4.6) \\
2.88, \mathrm{t}(12.9,12.9) \\
1.81, \mathrm{dd}(10.4,3.9) \\
6.84, \mathrm{~d}(7.0) \\
7.19, \mathrm{t}(7.3,7.3) \\
7.14, \mathrm{~d}(7.0)\end{array}$ & Ahp-5 & $\begin{array}{c}\text { Phe-2, Phe- } 1^{\prime}, \text { Phe- } 2^{\prime} / 6^{\prime} \\
\text { Phe-3a, Phe-3b, Phe- } 4^{\prime} \\
\text { Phe- } 1^{\prime} \\
\text { Phe C2 } 2^{\prime} / 6^{\prime}\end{array}$ \\
\hline MeTyr $^{5}$ & $\begin{array}{c}1 \\
2 \\
3 \\
1^{\prime} \\
2^{\prime} / 6^{\prime} \\
3^{\prime} / 5^{\prime} \\
4^{\prime} \\
\mathrm{NCH}_{3} \\
\mathrm{OH}\end{array}$ & $\begin{array}{c}169.4, \mathrm{C} \\
61.3, \mathrm{CH} \\
33.3, \mathrm{CH}_{2} \\
128.2, \mathrm{C} \\
130.9, \mathrm{CH} \\
115.5, \mathrm{CH} \\
156.7, \mathrm{C} \\
33.3, \mathrm{CH}_{3}\end{array}$ & $\begin{array}{c}4.89, \mathrm{dd}(8.9,2.5) \\
3.10, \mathrm{~m} \\
7.00, \mathrm{~d}(8.4) \\
6.78, \mathrm{~d}(8.4) \\
2.71, \mathrm{~s} \\
9.33, \mathrm{~s}\end{array}$ & Val-NH & $\begin{array}{c}\text { MeTyr-1 } \\
\text { MeTyr-1' } \\
\text { MeTyr-2' }{ }^{\prime} / 6^{\prime}, \text { MeTyr-3' } / 5^{\prime} \\
\text { MeTyr-2, Phe-1 } \\
\text { MeTyr-3 }{ }^{\prime} / 5^{\prime}, \text { MeTyr-4' }\end{array}$ \\
\hline $\mathrm{Val}^{6}$ & $\begin{array}{c}1 \\
2 \\
3 \\
4 \\
5 \\
\mathrm{NH}\end{array}$ & $\begin{array}{c}172.4, \mathrm{C} \\
56.3, \mathrm{CH} \\
31.4, \mathrm{CH} \\
19.7, \mathrm{CH}_{3} \\
17.7, \mathrm{CH}_{3}\end{array}$ & $\begin{array}{c}4.63, \mathrm{dd}(4.9,4.6) \\
2.02, \mathrm{~m} \\
0.84, \mathrm{~d}(6.6) \\
0.71, \mathrm{~d}(6.6) \\
7.39, \mathrm{~d}(9.7)\end{array}$ & MeTyr-2 & $\begin{array}{c}\text { Val-2, Val-3, Val-5 } \\
\text { Val-2, Val-3, Val-4 } \\
\text { MeTyr-1 }\end{array}$ \\
\hline
\end{tabular}

${ }^{a} \mathrm{HMBC}$ correlations are given from proton(s) stated to the indicated carbon atom. 
Table 4. NMR Spectroscopic data $\left(700 \mathrm{MHz}\right.$, DMSO- $\left.\mathrm{d}_{6}\right)$ for cyanopeptolin CPL962 $[$ Thr+Arg+Ahp+Phe+MePhe+Val]Asp+BA.

\begin{tabular}{|c|c|c|c|c|c|}
\hline Unit & Position & $\delta_{C}$ & $\delta_{\mathrm{H}}(J$ in $\mathrm{Hz})$ & ROESY & $\mathrm{HMBC}^{a}$ \\
\hline BA & $\begin{array}{l}1 \\
2 \\
3 \\
4\end{array}$ & $\begin{array}{l}172.2, \mathrm{C} \\
37.4, \mathrm{CH}_{2} \\
19.3, \mathrm{CH}_{2} \\
14.1, \mathrm{CH}_{3}\end{array}$ & $\begin{array}{c}2.08, \mathrm{~m} \\
1.52, \mathrm{~m} \\
0.87, \mathrm{t}(7.4,7.4)\end{array}$ & Asp-NH & $\begin{array}{c}\text { BA-1, BA-3, BA-4 } \\
\text { BA-1, BA-2, BA-4 } \\
\text { BA-2 }\end{array}$ \\
\hline Asp & $\begin{array}{c}1 \\
2 \\
3 \mathrm{a} \\
3 \mathrm{~b} \\
4 \\
\mathrm{NH}\end{array}$ & $\begin{array}{c}173.7, \mathrm{C} \\
50.8, \mathrm{CH} \\
40.1, \mathrm{CH}_{2} \\
175.3, \mathrm{C}\end{array}$ & $\begin{array}{c}4.54, \mathrm{~m} \\
2.51, \mathrm{~m} \\
2.12, \mathrm{~m} \\
8.00, \mathrm{~d}(8.0)\end{array}$ & Thr-NH & $\begin{array}{c}\text { Asp-2, Asp-4 } \\
\text { BA-1 }\end{array}$ \\
\hline Thr $^{1}$ & $\begin{array}{c}1 \\
2 \\
3 \\
4 \\
\mathrm{NH}\end{array}$ & $\begin{array}{l}169.9, \mathrm{C} \\
55.0, \mathrm{CH} \\
72.3, \mathrm{CH} \\
17.9, \mathrm{CH}_{3}\end{array}$ & $\begin{array}{c}4.58, \mathrm{~d}(9.0) \\
5.30, \mathrm{q}(6.8,6.5,6.8) \\
1.15, \mathrm{~d}(6.5) \\
7.23, \mathrm{~d}(7.6)\end{array}$ & $\begin{array}{l}\text { Arg-NH } \\
\text { Arg-NH } \\
\text { Asp-2 }\end{array}$ & $\begin{array}{l}\text { Thr-1 } \\
\text { Thr-4, Val-1 } \\
\text { Thr-2, Thr-3 }\end{array}$ \\
\hline $\operatorname{Arg}^{2}$ & $\begin{array}{c}1 \\
2 \\
3 \\
4 \\
5 \\
6 \\
\mathrm{NH}\end{array}$ & $\begin{array}{c}170.4, \mathrm{C} \\
49.0, \mathrm{CH} \\
26.4, \mathrm{CH}_{2} \\
24.5, \mathrm{CH}_{2} \\
39.8, \mathrm{CH}_{2} \\
158.7, \mathrm{C}\end{array}$ & $\begin{array}{c}4.15, \mathrm{~m} \\
1.88, \mathrm{~m} \\
1.46, \mathrm{~m} \\
2.95, \mathrm{~m} \\
8.5, \mathrm{~d}(8.7)\end{array}$ & $\begin{array}{c}\text { Ahp-NH } \\
\text { Thr-2, Thr-3 }\end{array}$ & Thr-1 \\
\hline$A h p^{3}$ & \begin{tabular}{|c|}
1 \\
2 \\
3 \\
4 \\
5 \\
$\mathrm{NH}$ \\
$\mathrm{OH}$
\end{tabular} & $\begin{array}{l}169.6, \mathrm{C} \\
48.6, \mathrm{CH} \\
21.7, \mathrm{CH}_{2} \\
22.0, \mathrm{CH}_{2} \\
74.2, \mathrm{CH}\end{array}$ & $\begin{array}{c}3.65, \mathrm{~m} \\
2.43, \mathrm{~m} \\
1.68, \mathrm{~m} \\
5.03, \mathrm{brs} \\
6.95, \mathrm{~d}(9.7) \\
6.01, \mathrm{~d}(2.6)\end{array}$ & $\begin{array}{c}\text { Phe-3a, Phe-3b } \\
\text { Arg-2, Ahp-3 }\end{array}$ & $\begin{array}{c}\text { Ahp-1, Ahp-3 } \\
\text { Ahp-1 } \\
\text { Arg-1 }\end{array}$ \\
\hline $\mathrm{Phe}^{4}$ & $\begin{array}{c}1 \\
2 \\
3 a \\
3 b \\
1^{\prime} \\
2^{\prime} / 6^{\prime} \\
3^{\prime} / 5^{\prime} \\
4^{\prime}\end{array}$ & $\begin{array}{c}170.0, \mathrm{C} \\
50.6, \mathrm{CH} \\
35.6, \mathrm{CH}_{2} \\
137.1, \mathrm{C} \\
129.8, \mathrm{CH} \\
128.2, \mathrm{CH} \\
126.7, \mathrm{CH}\end{array}$ & $\begin{array}{c}4.74, \mathrm{dd}(7.2,3.5) \\
2.86, \mathrm{~m} \\
1.69, \mathrm{~m} \\
6.78, \mathrm{~d}(7.1) \\
7.17, \mathrm{t}(7.1,7.1) \\
7.13, \mathrm{~d}(7.8)\end{array}$ & Ahp-5 & $\begin{array}{c}\text { Phe-1, Phe-3a, Phe-3b } \\
\text { Phe- } 1^{\prime} \\
\text { Phe-3a, Phe-3b, Phe- } 4^{\prime} \\
\text { Phe- } 1^{\prime} \\
\text { Phe- } 3^{\prime} / 5^{\prime}\end{array}$ \\
\hline MePhe $^{5}$ & $\begin{array}{c}1 \\
2 \\
3 \\
1^{\prime} \\
2^{\prime} / 6^{\prime} \\
3^{\prime} / 5^{\prime} \\
4^{\prime} \\
\mathrm{NCH}_{3}\end{array}$ & $\begin{array}{c}169.4, \mathrm{C} \\
60.9, \mathrm{CH} \\
34.4, \mathrm{CH}_{2} \\
138.4, \mathrm{C} \\
130.0, \mathrm{CH} \\
129.1, \mathrm{CH} \\
127.2, \mathrm{CH} \\
35.6, \mathrm{CH}_{3}\end{array}$ & $\begin{array}{c}5.02, \mathrm{~m} \\
3.23, \mathrm{~m} \\
7.24, \mathrm{~d}(7.6) \\
7.41, \mathrm{t}(7.7,7.7) \\
7.32, \mathrm{~d}(7.5) \\
2.84, \mathrm{~s}\end{array}$ & Val-NH & $\begin{array}{l}\text { MePhe- } 1^{\prime} \\
\text { MePhe- } 1^{\prime} \\
\text { MePhe- } 4^{\prime} \\
\text { MePhe-3' } / 5^{\prime} \\
\text { MePhe-2 }\end{array}$ \\
\hline $\mathrm{Val}^{6}$ & $\begin{array}{c}1 \\
2 \\
3 \\
4 \\
5 \\
\mathrm{NH}\end{array}$ & $\begin{array}{c}172.6, \mathrm{C} \\
56.4, \mathrm{CH} \\
31.6, \mathrm{CH} \\
19.7, \mathrm{CH}_{3} \\
17.8, \mathrm{CH}_{3}\end{array}$ & $\begin{array}{c}4.71, \mathrm{dd}(5.2,4.2) \\
2.05, \mathrm{~m} \\
0.88, \mathrm{~d}(6.9) \\
0.76, \mathrm{~d}(6.9) \\
7.41, \mathrm{~d}(7.7)\end{array}$ & MePhe-2 & $\begin{array}{c}\text { Val-3 } \\
\text { Val-2, Val-3, Val-5 } \\
\text { Val-2, Val-3, Val-4 } \\
\text { MePhe-1 }\end{array}$ \\
\hline
\end{tabular}

${ }^{a}$ HMBC correlations are given from proton(s) stated to the indicated carbon atom. 


\subsection{Bioassays}

Preparative chromatography resulted in separation of several fractions containing thirteen pure cyanopeptolin variants (Table 2). These peptides were evaluated for inhibition against four serine proteases and protein phosphatase 1. In addition, their effect on MCF-7 breast cancer cells was tested. However, only six CPs were isolated from N. edaphicum CCNP1411 in sufficient amounts to obtain quantitative results of the assays. None of the peptides were active against thrombin, elastase, and protein phosphatase 1 , even at the highest concentration used in the study $(45.4 \mu \mathrm{g} / \mathrm{mL})$. However, all CPs with Arg in position 2 significantly reduced the activity of trypsin. The $\mathrm{IC}_{50}$ values of trypsin inhibitors were comparable and in the range of $0.24-0.26 \mu \mathrm{M}$. The CPs- $\mathrm{Arg}^{2}$ with $\mathrm{N}$-MeTyr or N-MeHty in position 5 were also active against chymotrypsin, but the $\mathrm{IC}_{50}$ values were lower $\left(\mathrm{IC}_{50}=3.1-3.8 \mu \mathrm{M}\right)$. Chymotrypsin inhibition activity of CPs-Arg ${ }^{2}$ was not observed when position 5 was occupied by MePhe. All CPs-Tyr ${ }^{2}$ reduced activity of chymotrypsin and were inactive against other enzymes. For $\mathrm{CP} 1027$ and $\mathrm{CP} 985$, the $\mathrm{IC}_{50}$ was $0.26 \mu \mathrm{M}$. Following enzyme inhibition assays, all samples with $\mathrm{Arg}^{2}$-containing CP962 and $\mathrm{Tyr}^{2}$-containing CP985 (at $4.54 \mu \mathrm{g} / \mathrm{mL}$ ) were analyzed by LC-MS/MS. The recovery was based on extracted mass chromatogram of parent ions. The enzymes did not cause any significant loss of the peptides; their contents were in the range from $94.6 \%$ to $97.7 \%$ of that in samples without the enzyme.

Due to limited amounts of pure peptides isolated from N. edaphicum CCNP1411, only $\mathrm{Arg}^{2}$-containing CP962 and $\mathrm{Tyr}^{2}$-containing CP985 were used in MTT (3-(4,5-dimethylthiazole-2-yl)2,5-diphenyltetrazolium bromide) assay. After 24-h exposure, no cytotoxic effects on the MCF-7 cells were observed (Figure 5).

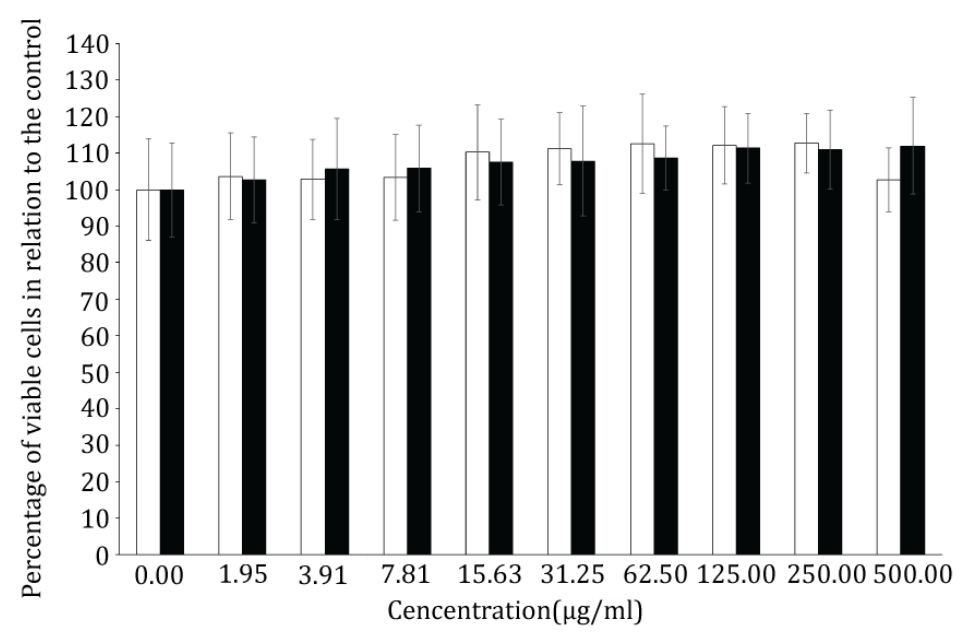

Figure 5. Viability of breast cancer cells MCF-7 treated for $24 \mathrm{~h}$ with $\mathrm{Arg}^{2}$-containing CP962 (white bars) and $\mathrm{Tyr}^{2}$-containing CP985 (black bars), isolated from N. edaphicum CCNP1411. Data are presented as percentage of the control, mean \pm s.e.m, $n=3$.

\section{Discussion}

Cyanobacteria from the Nostoc genus, especially the symbiotic strains and those living in waters from tropical regions, are important producers of bioactive compounds with potential biotechnological or pharmaceutical application [37,40-43]. One of the most prominent examples are cryptophycins, cyclic depsipeptides isolated from Nostoc sp. ATCC 53789 and GSV 224. They are promising candidates for anti-cancer drug development [44,45]. Another important Nostoc metabolite is cyanovirin-N, a small cyanobacterial lectin which blocks the entry of the enveloped viruses such as HIV, influenza, and Ebola [46].

In this study, the structures of CPs produced by N. edaphicum CCNP1411 from the Baltic Sea were elucidated based on the fragmentation spectra of their pseudomolecular ions (CPs-Arg ${ }^{2}$ ) 
(Figure 4; Figures S2-S8) or the dehydrated forms of the ions (CPs-Tyr ${ }^{2}$ ) (Figure 3; Figures S9-S12). The occurrence of the dehydrated pseudomolecular ion as a precursor ion in mass fragmentation spectra of $\mathrm{Tyr}^{2}$-(and $\mathrm{Ile}^{2}$ )-containing aeruginopeptins has been previously reported [20,47]. It was suggested that the cleavage of an ester bond at $\mathrm{Thr}^{1}$ and subsequent dehydration resulted in the generation of linear peptides. For the two CPs, $\mathrm{Arg}^{2}$-containing CP962 and $\mathrm{Tyr}^{2}$-containing CP985, the composition and sequences of amino acids were confirmed by NMR spectroscopy. The results of the analyses were consistent with structure elucidation performed by tandem mass spectrometry. The core structures of these peptides were more similar to those identified in Microcystis [13,14,28,32], compared to those reported from other Nostoc isolates (Table 1). For example, instead of $\mathrm{Arg}^{2} \mathrm{or} \mathrm{Tyr}^{2}$ present in position 2 of the CPs identified in this work, nostopeptin and insulapeptolides from $N$. minutum and $\mathrm{N}$. insulare possess $\mathrm{Leu}^{2} \mathrm{or} \mathrm{Hph}^{2}$ (homophenylalanine) [35,38]. Of the CPs identified in this study, only CP1006A ( $m / z$ 1007) was previously reported. This peptide, along with its chlorinated derivative (CP1040A) were found in Microcystis bloom and culture samples [14,48].

The structural diversity of CPs, specifically the residue in position 2, was found to have significant effect on activity of the peptides against serine proteases: trypsin and chymotrypsin $[28,29,32]$. The CP-type peptides with potent inhibitory activity against trypsin were characterized by the presence of basic amino acid (Arg or Lys), whereas in peptides active against chymotrypsin, position 2 was occupied by hydrophobic residues (Tyr, Phe, Hty or Leu). The same structure-activity relationship was observed in this study. Eight CPs-Arg ${ }^{2}$ inhibited the activity of trypsin with $\mathrm{IC}_{50}$ values of $0.24-0.26 \mu \mathrm{M}$, and five CPs-Tyr ${ }^{2}$ inhibited chymotrypsin with similar potency. In addition, the inhibitory activity of CPs produced by CCNP1411 seemed to be affected by the residue in position 5. Only those CPs-Arg ${ }^{2}$ which had $\mathrm{N}$-MeTyr ${ }^{5}$ or $\mathrm{N}-\mathrm{MeHty}^{5}$ in this position were active against chymotrypsin. However, to unequivocally prove the significance of this structure-activity relationship, more CPs should be tested. The fact that some CPs- $\mathrm{Arg}^{2}$, apart from strong inhibition of trypsin, are also active against chymotrypsin was previously documented by other authors $[12,29,49]$. The trypsin inhibition activity of CP-type peptides was suggested to be enhanced by the presence of isoleucine in position 6, instead of valine. Other modifications in the structure of Ahp-containing cyclic depsipeptides, such as the presence of chloride or sulfide groups, may also have an effect on enzyme inhibition activity [12].

Cyanobacteria produce many other Ahp-containing cyclic depsipeptides with inhibitory activity against proteases $[28,29]$. The majority of the peptides were active at micromolar concentrations, but some had even lower $\mathrm{IC}_{50}$ values. Symplocamide A, with citrulline in position 2, showed potent activity against chymotrypsin with $\mathrm{IC}_{50}$ of $0.38 \mu \mathrm{M}$, and was 200-times less active against trypsin $\left(\mathrm{IC}_{50} 80.2 \mu \mathrm{M}\right)$ [29]. Symplocamide A also had cytotoxic activity to NCI H460 lung cancer cells and neuro-2A neuroblastoma cells [29]. Chymotrypsin was most potently inhibited by the glyceric acid 3'-O-phosphate-containing micropeptin T20 from M. aeruginosa, characterized by the presence of the Thr-Phe-Ahp sequence ( $\mathrm{IC}_{50} 2.5 \mathrm{nM}$ ) [50]. Picomolar inhibition of trypsin was documented for $\mathrm{CP}$ 1020, which was also active against chymotrypsin, plasmin, human kallikrein, and factor XIa [32]. The structure of CP1020 differs from CP978 isolated in our study only in the presence of Glu in a side chain, instead of Asp. In enzymatic assays, CP978 and other CPs isolated from N. edaphicum CCNP1411 were less active than CP1020, but still belong to the most potent protease inhibitors among this class of compounds $[12,28,29,32]$. Ahp-containing depsipeptides were suggested to block the active center of trypsin or/and chymotrypsin, so the enzymes cannot cleave the peptide bonds at the carboxyl side of Arg or Tyr, respectively $[25,28]$. In this study, the $\mathrm{Tyr}^{2}$-containing CP985 and $\mathrm{Arg}^{2}$-containing CP962 exposed to proteases inhibited the activity of chymotrypsin or/and trypsin, but their concentrations remained almost unchanged. These results are in line with the hypothesis by Yamaki et al. [28] and confirm the blockage of the active centers of the enzymes by the peptides.

Trypsin and chymotrypsin, the two enzymes inhibited by CPs from CCNP1411, are essential for food digestion. Their deregulation can also lead to a number of human diseases such as cancer, cardiovascular and inflammatory diseases. The molecules that modify activity of these proteases, and especially those that act selectively, are widely explored as agents of significant biotechnological 
and pharmaceutical potential [51]. As the new CP variants identified in N. edaphicum CCNP1411 inhibited the activity of trypsin or chymotrypsin at low concentrations and were inactive against the other tested enzymes and MCF-7 breast cancer cells, their possible use as therapeutic agents should be further explored.

Besides its therapeutic potential, this class of protease inhibitors was proven to be an important group of defense agents protecting cyanobacteria from grazers. Oscillapeptin J, CP SS and CP 1020 induced acute effects in small crustaceans $[18,32,33]$. However, CP SS was not toxic to the isolated rat hepatocytes [18], and oscillapeptin J did not induce any harmful effects in mice when administered intraperitoneally at concentrations up to $1000 \mu \mathrm{g} / \mathrm{kg}$ b.w. [52]. In the case of CP1020, induction of anti-inflammatory effects in human hepatoma cell line Huh7 was observed [53]. In addition, exposure of zebrafish eleuthero-embryos to CP1020 led to transcriptional alterations of genes involved in many important processes, including DNA damage recognition and repair, and circadian rhythm [54]. These findings, along with the acute toxicity of CP-type compounds observed in crustaceans suggest that their activity is not only related to the inhibition of digestive enzymes.

\section{Materials and Methods}

\subsection{Culture Conditions}

Nostoc cf. edaphicum CCNP 1411 (GenBank accession number KJ161445) was isolated in 2010 from the Gulf of Gdańsk, southern Baltic Sea, and established as monospecies culture by Dr. Justyna Kobos. Purification of the strain was carried out by multiple transfer to a liquid or/and solid ( $1 \%$ bacterial agar) Z8S medium [55]. To obtain a higher biomass of the cyanobacterium, the culture was grown in 5 - $\mathrm{L}$ bottles at $22{ }^{\circ} \mathrm{C} \pm 1{ }^{\circ} \mathrm{C}$, at continuous light of $10-30 \mu \mathrm{E} / \mathrm{m}^{2} / \mathrm{s}$. The collected biomass was lyophilized and kept at $-20^{\circ} \mathrm{C}$ until used.

\subsection{Extraction and Isolation}

Freeze-dried biomass of $N$. edaphicum ( $36 \mathrm{~g}$ ) was extracted twice with $75 \%$ methanol $(\mathrm{MeOH})$ $(1 \mathrm{~L})$ by vortexing for $30 \mathrm{~min}$. Following centrifugation at 4,000 $\mathrm{g}$, the extracts were pooled and diluted in water purified using ELGA PURELAB ${ }^{\circledR}$ flex (Veoilia, London, UK) to adjust the concentration of $\mathrm{MeOH}$ to $<10 \%$. Then, the sample was loaded onto the preconditioned 120-g SNAP KP-C18-HS cartridge (Biotage Uppsala, Sweden). Sample components were eluted using an Isolera flash chromatography system (Biotage Uppsala, Sweden), with a step gradient $(10-100 \% \mathrm{MeOH}$ in water) with 3 column volumes of eluent at each step. Absorbance was monitored at $210 \mathrm{~nm}$ and $280 \mathrm{~nm}$. The flow rate was $40 \mathrm{~mL} / \mathrm{min}$ and $60-\mathrm{mL}$ fractions were collected. Fraction composition was analyzed by UPLC-MS/MS. Fractions containing the same peptides were pooled, diluted with water to $<10 \% \mathrm{MeOH}$, and concentrated on YMC C18 cartridges ( $20 \mathrm{~mm} \mathrm{ID} \times 2 \mathrm{~cm}$; YMC, Gmbh, Dinslaken, Germany).

Six pooled fractions were further purified using preparative HPLC (Biotage Parallex Flex, Cardiff, UK) and Flex V3 software for instrument control and data acquisition. The separation was performed on XBridge Prep C18 column ( $5 \mu \mathrm{m}$ CBD, 19 mm ID $\times 250$ mm long; Waters, Elstree, UK) using a 30 -min linear gradient from $15 \%$ to $80 \%$ acetonitrile in MilliQ water with $0.1 \%$ formic acid. Absorbance was monitored at $210 \mathrm{~nm}$ and $280 \mathrm{~nm}$. The flow rate was $20 \mathrm{~mL} / \mathrm{min}$ and $4-\mathrm{mL}$ fractions were collected.

\subsection{LC-MS/MS Analyses}

At each step of the extraction and isolation procedure, the content of the collected fractions was determined by UPLC-MS/MS. The system comprised a Waters Acquity Ultra performance LC coupled to a photodiode array detector (PDA) and a Xevo quadrupole time of flight mass detector (Waters, Elstree, UK). Samples were separated on an ethylene-bridged hybride BEH C18 column $\left(2.1 \mathrm{~mm}\right.$ ID $\times 100 \mathrm{~mm} ; 1.7 \mu \mathrm{m}$, Waters) maintained at $40{ }^{\circ} \mathrm{C}$. The mobile phase was Milli-Q water and acetonitrile (solvent $\mathrm{B}$ ), both containing $0.1 \%$ formic acid. Separation was performed using 
gradient elution $(0.3 \mathrm{~mL} / \mathrm{min})$ from $20 \%$ to $70 \%$ B over $10 \mathrm{~min}$, followed by a $100 \%$ B wash step and re-equilibration. Data was acquired in positive ion electrospray scanning from $m / z 50$ to 2000 with a scan time of $2 \mathrm{~s}$ and inter-scan delay of $0.1 \mathrm{~s}$. The capillary and cone voltages were set at $0.7 \mathrm{kV}$ and $25 \mathrm{~V}$, respectively. The desolvation gas was maintained at $400 \mathrm{~L} / \mathrm{h}$ at a temperature of $300{ }^{\circ} \mathrm{C}$. The cone gas was set at $50 \mathrm{~L} / \mathrm{h}$ with a source temperature of $80^{\circ} \mathrm{C}$. Instrument control, data acquisition and processing were achieved using MassLynx v4.1 (Waters, Milford, MA, USA).

Structures of cyanopeptolins were additionally characterized using Agilent 1200 HPLC (Agilent Technologies, Waldbronn, Germany) coupled to a hybrid triple quadrupole/linear ion trap mass spectrometer QTRAP5500 (Applied Biosystems MDS Sciex, Concord, ON, Canada). Peptides were separated on Zorbax Eclipse XDB-C18 column (4.6 mm ID $\times 150 \mathrm{~mm}, 5 \mu \mathrm{m}$; Agilent Technologies, Santa Clara, CA, USA) column. A gradient elution $(0.6 \mathrm{~mL} / \mathrm{min})$ was applied with mobile phase composed of $5 \%$ acetonitrile in MilliQ water and acetonitrile (solvent B), both containing $0.1 \%$ formic acid. The gradient started at $15 \% \mathrm{~B}$ and went to $50 \% \mathrm{~B}$ within $5 \mathrm{~min}$. The content of phase $\mathrm{B}$ was then increased to $100 \%$ within the next $3 \mathrm{~min}$ and kept at that level for $10 \mathrm{~min}$ before returning to the starting conditions. The QTRAP MS/MS system was operated in the positive mode, with turbo ion source voltage set at $5.5 \mathrm{kV}$ and temperature at $550^{\circ} \mathrm{C}$. For ions within the $\mathrm{m} / z$ range $500-1250$ and signal intensity above the threshold of 500,000 cps, fragmentation spectra were acquired within a range 50-1000 Da, at collision energy of $60 \mathrm{~V}$ and declustering potential set at $80 \mathrm{eV}$. Data acquisition and processing were accomplished with the Analyst ${ }^{\circledR}$ Sofware (version 1.5.1, Applied Biosystems, Concord, ON, Canada).

\subsection{NMR Analyses}

1D ${ }^{1} \mathrm{H}-\mathrm{NMR}$ and 2D homo- and heteronuclear 2D NMR (COSY, TOCSY, ROESY, HSQC, and $\mathrm{HMBC}$ ) were acquired on a Bruker Avance III spectrometers, $500 \mathrm{MHz}$ and $700 \mathrm{MHz}$. Spectra were recorded in DMSO- $\mathrm{d}_{6}$. NMR data were processed and analyzed by TopSpin (Bruker, Billerica, MA, USA) and SPARKY software (3.114, Goddard and Kneller, freeware https: / /www.cgl.ucsf.edu / home/sparky).

\subsection{Enzyme Inhibition Assay}

The chymotrypsin and trypsin inhibition assays were performed following the procedures of Ploutno and Carmeli [41]. The $\alpha$-chymotrypsin from bovine pancreas (C4129), trypsin from porcine pancreas (T0303), aprotinin $(1.5-200 \mu \mathrm{g} / \mathrm{mL})$ as enzyme inhibitor, $N$-Suc-Gly-Gly-p-nitroanilide and $N$ - $\alpha$-benzoyl-DL-arginine- $p$-nitroanilide hydrochloride (BAPNA) as chymotrypsin and trypsin substrates, respectively were used. Enzymes $(0.1 \mathrm{mg} / \mathrm{mL})$ and substrate $(2 \mathrm{mM})$ were dissolved in the same buffer (50 mM Tris- $\mathrm{HCl}, 100 \mathrm{mM} \mathrm{NaCl}, 1 \mathrm{mM} \mathrm{CaCl}_{2}, \mathrm{pH} 7.5$ ). The thrombin inhibition assay was performed according to Ocampo and Bennet [56]. Thrombin (T4648) was dissolved in buffer $(0.5 \mathrm{mg} / \mathrm{mL} ; 0.2 \mathrm{M}$ Tris-HCl; $\mathrm{pH} 8.0)$; substrate ( $\mathrm{N}$ - -tosyl-Gly-L-Pro-L-Lys- $p$-nitroanilide acetate salt, $0.5 \mathrm{mg} / \mathrm{mL}$ ) and inhibitor (4-(2-aminoethyl)benzenesulfonyl fluoride hydrochloride (AEBSF; $60-2400 \mu \mathrm{g} / \mathrm{mL})$ ) were dissolved in MilliQ water. The elastase inhibition assay was performed according to Kwan et al. [57]. The enzyme $(75 \mu \mathrm{g} / \mathrm{mL}$; E0258) from porcine pancreas, substrate (2 $\mathrm{mM}$; N-Suc-Ala-Ala-Ala- $p$-nitroanilide) and inhibitor (elastatinal; $5-125 \mu \mathrm{g} / \mathrm{mL}$ ) were dissolved in buffer (0.2 M Tris-HCl; pH 8.0). All enzymes, substrates and inhibitors used for proteases inhibition assays were from Sigma-Aldrich (St. Louis, MO, USA). Protein phosphatase 1 inhibition assay was performed according to the procedure described by Rapala et al. [58]. PP1 was from England Biolabs, Hitchin, UK (754S) and the substrate, $p$-nitrophenyl phosphate disodium salt hexahydrate ( $p$-NPP), was from Sigma-Aldrich (Irvine, UK). Microcystin MC-LR (0.125-4.0 ng/mL) from Enzo Life Sciences, Lausen, Switzerland was used as inhibitor. The enzyme was dissolved in buffer solution A (50 $\mathrm{mM}$ Tris at $\mathrm{pH} 7.4,1 \mathrm{mg} / \mathrm{mL}$ bovine serum albumin (BSA; Sigma -Aldrich, St. Louis, MO, USA), $1 \mathrm{mM} \mathrm{MnCl}_{2}, 2 \mathrm{mM}$ dithiotreitol (DTT; Sigma-Aldrich, St. Louis, MO, USA)). $p$-NPP $(5.5 \mathrm{mg} / \mathrm{mL}$ ) was dissolved in buffer solution $\mathrm{B}\left(50 \mathrm{mM}\right.$ Tris, $\mathrm{pH} 8.1,0.5 \mathrm{mg} / \mathrm{mL} \mathrm{BSA}, 20 \mathrm{mM} \mathrm{MgCl} 2 \times 6 \mathrm{H}_{2} \mathrm{O}$, 
$200 \mathrm{mM} \mathrm{MnCl} \mathrm{M}_{2} \times 4 \mathrm{H}_{2} \mathrm{O}$ ). All enzyme inhibition assays were performed in a 96 multi-well plate at $37^{\circ} \mathrm{C}$, in triplicate. The absorbance of the reaction mixtures was measured at $405 \mathrm{~nm}$ using a microplate reader (Molecular Devices, Sunnyvale, CA, USA). After trypsin and chymotrypsin inhibition assays, the samples with and without the enzymes and containing the highest concentration of CP962 and CP985 $(45.4 \mu \mathrm{g} / \mathrm{mL})$ were analyzed by LC-MS/MS. The content of the peptides was determined based of the peak area of the extracted ions.

\subsection{Cytotoxicity Assay}

For the test, two CPs were selected: $\mathrm{Arg}^{2}$-containing CP962 and $\mathrm{Tyr}^{2}$-containing CP985. MCF-7 breast cancer cells were seeded at $7.5 \times 10^{3}$ cells $/ 100 \mu \mathrm{L}$ in a 96 -well plates and incubated at $37^{\circ} \mathrm{C}, 5 \%$ $\mathrm{CO}_{2}$ for $24 \mathrm{~h}$. The cells were then treated for a further $24 \mathrm{~h}$ with CP962 and CP985 (0 to $500 \mu \mathrm{g} / \mathrm{mL}$ ). After $24 \mathrm{~h}$, sterile-filtered 3-(4,5-dimethylthiazol-2-yl)-2,5-diphenyltetrazolium bromide solution (MTT; $1 \mathrm{mg} / \mathrm{mL}$ ) was added to each well. After $4 \mathrm{~h}$ incubation at $37^{\circ} \mathrm{C}$ in the dark, the MTT solution was removed and formazan crystals solubilized in DMSO. The plates were shaken for $20 \mathrm{~min}$, in the dark, at room temperature and absorbance was measured at $560 \mathrm{~nm}$ (Synergy/HT, BIOTEK, Wnooski, VT, USA). For each CP, three independent experiments were carried out and each treatment consisted of six replicates per plate. Bar charts were used to represent the viability of MCF-7 cells treated with CP962 and CP985, compared to the control (i.e., untreated cells) that represented $100 \%$ cell viability.

\section{Conclusions}

Nostoc edaphicum CCNP1411 isolated from the Gulf of Gdańsk (southern Baltic) produces at least thirteen CPs, including twelve variants reported here for the first time. The structures of the peptides are different from other Ahp-containing cyclic depsipeptides previously found in Nostoc. The activity of the peptides was mainly determined by the presence of $\mathrm{Arg}^{2}$ or $\mathrm{Tyr}^{2}$ in Ahp-adjacent position. The fact that trypsin and chymotrypsin did not degrade the tested CPs constitutes an additional evidence for enzyme inactivation by the peptides. Neither of the $\mathrm{CP}$ inhibited thrombin, elastase, and protein phosphatase 1; CP962 and CP985 also showed no cytotoxic effects on MCF-7 breast cancer cells. The CPs produced by N. edaphicum CCNP1411, as peptidic structures with selective and potent proteases inhibiting activity, are potential lead compounds in drug discovery process.

Supplementary Materials: The following are available online at http:/ /www.mdpi.com/1660-3397/16/7/220/s1. Figure S1: LC-MS/MS chromatogram of cyjanopeptolins (CPs) in crude extract from Nostoc edaphicum CCNP1411 (A) and chromatograms of isolated peptides: CP962 (B) and CP985 (C); Figure S2: Chemical structure (A) and product ion mass spectra of cyanopeptolin CP1049 [Thr+Arg+Ahp+Phe+MeHty+Val]Asp+OA with precursor ion $[\mathrm{M}+\mathrm{H}]^{+}$at $m / z$ 1049. The spectra were recorded with application of a hybride quadrupole/time-of-flight mass spectrometer (QTOF) (B) and a hybride triple quadrupole/linear ion trap mass spectrometer (QTRAP) (C). The mass signals were assigned to the following fragments: $1031\left[\mathrm{M}+\mathrm{H}-\mathrm{H}_{2} \mathrm{O}^{+}, 1003\left[\mathrm{M}+\mathrm{H}-\mathrm{H}_{2} \mathrm{O}\right.\right.$ $-\mathrm{CO}^{+}, 932\left[\mathrm{M}+\mathrm{H}-\mathrm{Val}-\mathrm{H}_{2} \mathrm{O}\right]^{+}, 914\left[\mathrm{M}+\mathrm{H}-\mathrm{Val}-2 \mathrm{H}_{2} \mathrm{O}\right]^{+}, 808[\mathrm{M}+2 \mathrm{H}-(\mathrm{Asp}+\mathrm{OA})]^{+}, 790[\mathrm{M}+2 \mathrm{H}$ $\left.-(\mathrm{Asp}+\mathrm{OA})-\mathrm{H}_{2} \mathrm{O}\right]^{+}, 772\left[\mathrm{M}+2 \mathrm{H}-(\mathrm{Asp}+\mathrm{OA})-2 \mathrm{H}_{2} \mathrm{O}\right]^{+}, 741\left[\mathrm{M}+\mathrm{H}-(\mathrm{Val}+\mathrm{MeHty})-\mathrm{H}_{2} \mathrm{O}\right]^{+}, 673$ $\left[\mathrm{M}+2 \mathrm{H}-\mathrm{Val}-(\mathrm{Asp}+\mathrm{OA})-2 \mathrm{H}_{2} \mathrm{O}\right]^{+}, 481\left[\mathrm{OA}+\mathrm{Asp}+\mathrm{Thr}+\mathrm{Arg}+\mathrm{H}-\mathrm{H}_{2} \mathrm{O}\right]^{+}, 434[\mathrm{Ahp}+\mathrm{Phe}+\mathrm{MeHty}$ $\left.+\mathrm{H}-\mathrm{H}_{2} \mathrm{O}\right]^{+}, 338\left[\mathrm{Arg}+\mathrm{Thr}+\mathrm{Val}+\mathrm{H}-\mathrm{H}_{2} \mathrm{O}\right]^{+}, 322[\mathrm{Phe}(-\mathrm{N})+\mathrm{MeHty}+\mathrm{H}]^{+}, 297[\mathrm{Asp}+\mathrm{Thr}+\mathrm{Val}+\mathrm{H}$ $\left.-\mathrm{H}_{2} \mathrm{O}\right]^{+}, 243\left[\mathrm{Ahp}+\mathrm{Phe}+\mathrm{H}-\mathrm{H}_{2} \mathrm{O}\right]^{+}, 215\left[\mathrm{Ahp}+\mathrm{Phe}+\mathrm{H}-\mathrm{H}_{2} \mathrm{O}-\mathrm{CO}\right]^{+}, 164 \mathrm{MeHty}$ immonium ion, 120 Phe immonium ion, 70-Arg; Figure S3: Chemical structure (A) and product ion mass spectra of cyanopeptolin $\mathrm{CP} 1020[\mathrm{Thr}+\mathrm{Arg}+\mathrm{Ahp}+\mathrm{Phe}+\mathrm{MeHty}+\mathrm{Val}] \mathrm{Asp}+\mathrm{HA}$ with precursor ion $[\mathrm{M}+\mathrm{H}]^{+}$at $m / z 1021$. The spectra were recorded with application of QTOF $(\mathbf{B})$ and QTRAP $(\mathbf{C})$ mass spectrometers. The mass signals were assigned to the following fragments: $1003\left[\mathrm{M}+\mathrm{H}-\mathrm{H}_{2} \mathrm{O}\right]^{+}, 975\left[\mathrm{M}+\mathrm{H}-\mathrm{H}_{2} \mathrm{O}-\mathrm{CO}\right]^{+}, 886\left[\mathrm{M}+\mathrm{H}-\mathrm{Val}-2 \mathrm{H}_{2} \mathrm{O}\right]^{+}, 808$ $[\mathrm{M}+2 \mathrm{H}-(\mathrm{Asp}+\mathrm{HA})]^{+}, 790\left[\mathrm{M}+2 \mathrm{H}-(\mathrm{Asp}+\mathrm{HA})-\mathrm{H}_{2} \mathrm{O}\right]^{+}, 772\left[\mathrm{M}+2 \mathrm{H}-(\mathrm{Asp}+\mathrm{OA})-2 \mathrm{H}_{2} \mathrm{O}\right]^{+}, 713[\mathrm{M}+$ $\left.\mathrm{H}-(\mathrm{Val}+\mathrm{MeHty})-\mathrm{H}_{2} \mathrm{O}\right]^{+}, 691\left[\mathrm{M}+2 \mathrm{H}-\mathrm{Val}-(\mathrm{Asp}+\mathrm{HA})-\mathrm{H}_{2} \mathrm{O}\right]^{+}, 673[\mathrm{M}+2 \mathrm{H}-\mathrm{Val}-(\mathrm{Asp}+\mathrm{HA})-$ $\left.2 \mathrm{H}_{2} \mathrm{O}\right]^{+}, 453\left[\mathrm{HA}+\mathrm{Asp}+\mathrm{Thr}+\mathrm{Arg}+\mathrm{H}-\mathrm{H}_{2} \mathrm{O}\right]^{+}, 434\left[\mathrm{Ahp}+\mathrm{Phe}+\mathrm{MeHty}+-\mathrm{H}_{2} \mathrm{O}\right]^{+}, 338[\mathrm{Arg}+\mathrm{Thr}+\mathrm{Val}+\mathrm{H}$ $\left.-\mathrm{H}_{2} \mathrm{O}\right]^{+}, 322[\mathrm{Phe}(-\mathrm{N})+\mathrm{MeHty}+\mathrm{H}]^{+}, 297\left[\mathrm{Asp}+\mathrm{Thr}+\mathrm{Val}+\mathrm{H}-\mathrm{H}_{2} \mathrm{O}\right]^{+}, 243\left[\mathrm{Ahp}+\mathrm{Phe}+\mathrm{H}-\mathrm{H}_{2} \mathrm{O}\right]^{+}, 215$ $\left[\mathrm{Ahp}+\mathrm{Phe}+\mathrm{H}-\mathrm{H}_{2} \mathrm{O}-\mathrm{CO}^{+}{ }^{+}, 164 \mathrm{MeHty}\right.$ immonium ion, 120 Phe immonium ion, 70-Arg; Figure S4: Chemical structure (A) and product ion mass spectra of cyanopeptolin CP1018 [Thr+Arg+Ahp+Phe+MePhe+Val]Asp+OA with precursor ion $[\mathrm{M}+\mathrm{H}]^{+}$at $m / z$ 1019. The spectra were recorded with application of QTOF (B) and QTRAP (C) mass spectrometers. The mass signals were assigned to the following fragments: $1001\left[\mathrm{M}+\mathrm{H}-\mathrm{H}_{2} \mathrm{O}\right]^{+}, 983[\mathrm{M}+$ $\left.\mathrm{H}-2 \mathrm{H}_{2} \mathrm{O}\right]^{+}, 973\left[\mathrm{M}+\mathrm{H}-\mathrm{H}_{2} \mathrm{O}-\mathrm{CO}\right]^{+}, 902\left[\mathrm{M}+\mathrm{H}-\mathrm{Val}-\mathrm{H}_{2} \mathrm{O}\right]^{+}, 884\left[\mathrm{M}+\mathrm{H}-\mathrm{Val}-2 \mathrm{H}_{2} \mathrm{O}\right]^{+}, 778[\mathrm{M}+2 \mathrm{H}$ $-(\mathrm{Asp}+\mathrm{OA})]^{+}, 760\left[\mathrm{M}+2 \mathrm{H}-(\mathrm{Asp}+\mathrm{OA})-\mathrm{H}_{2} \mathrm{O}\right]^{+}, 742\left[\mathrm{M}+2 \mathrm{H}-(\mathrm{Asp}+\mathrm{OA})-2 \mathrm{H}_{2} \mathrm{O}\right]^{+}, 661[\mathrm{M}+2 \mathrm{H}-\mathrm{Val}$ $\left.-(\mathrm{Asp}+\mathrm{OA})-\mathrm{H}_{2} \mathrm{O}\right]^{+}, 643\left[\mathrm{M}+2 \mathrm{H}-\mathrm{Val}-(\mathrm{Asp}+\mathrm{OA})-2 \mathrm{H}_{2} \mathrm{O}\right]^{+}, 481\left[\mathrm{OA}+\mathrm{Asp}+\mathrm{Thr}+\mathrm{Arg}+\mathrm{H}-\mathrm{H}_{2} \mathrm{O}\right]^{+}$, 
$404\left[\mathrm{Ahp}+\mathrm{Phe}+\mathrm{MePhe}+\mathrm{H}-\mathrm{H}_{2} \mathrm{O}\right]^{+}, 338\left[\mathrm{Arg}+\mathrm{Thr}+\mathrm{Val}+\mathrm{H}-\mathrm{H}_{2} \mathrm{O}\right]^{+}, 308[\mathrm{Phe}(-\mathrm{N})+\mathrm{MeTyr}+\mathrm{H}]^{+}, 297$ $\left[\right.$ Asp $+\mathrm{Thr}+\mathrm{Val}+\mathrm{H}-\mathrm{H}_{2} \mathrm{O}^{+}, 243\left[\mathrm{Ahp}+\mathrm{Phe}+\mathrm{H}-\mathrm{H}_{2} \mathrm{O}\right]^{+}, 215\left[\mathrm{Ahp}+\mathrm{Phe}+\mathrm{H}-\mathrm{H}_{2} \mathrm{O}-\mathrm{CO}\right]^{+}, 134 \mathrm{MePhe}$ immonium ion, 120 Phe immonium ion, 70-Arg; Figure S5: Chemical structure (A) and product ion mass spectra of cyanopeptolin CP1006 [Thr+Arg+Ahp+Phe+MeTyr+Val]Asp+HA with precursor ion $[\mathrm{M}+\mathrm{H}]^{+}$at $m / z 1007$. The spectra were recorded with application of QTOF (B) and QTRAP (A) mass spectrometers. The mass signals were assigned to the following fragments: $989\left[\mathrm{M}+\mathrm{H}-\mathrm{H}_{2} \mathrm{O}\right]^{+}, 961\left[\mathrm{M}+\mathrm{H}-\mathrm{H}_{2} \mathrm{O}-\mathrm{CO}\right]^{+}, 872[\mathrm{M}+\mathrm{H}-\mathrm{Val}-$ $\left.2 \mathrm{H}_{2} \mathrm{O}\right]^{+}, 794[\mathrm{M}+2 \mathrm{H}-(\mathrm{Asp}+\mathrm{HA})]^{+}, 776\left[\mathrm{M}+2 \mathrm{H}-(\mathrm{Asp}+\mathrm{HA})-\mathrm{H}_{2} \mathrm{O}^{+}, 766[\mathrm{M}+2 \mathrm{H}-(\mathrm{Asp}+\mathrm{HA})-\mathrm{CO}]^{+}\right.$, $758\left[\mathrm{M}+2 \mathrm{H}-(\mathrm{Asp}+\mathrm{HA})-2 \mathrm{H}_{2} \mathrm{O}^{+}, 713\left[\mathrm{M}+\mathrm{H}-(\mathrm{Val}+\mathrm{MeHTyr})-\mathrm{H}_{2} \mathrm{O}\right]^{+}, 659[\mathrm{M}+2 \mathrm{H}-\mathrm{Val}-(\mathrm{Asp}+\mathrm{HA})\right.$ $-2 \mathrm{H}_{2} \mathrm{O}^{+}, 453\left[\mathrm{HA}+\mathrm{Asp}+\mathrm{Thr}+\mathrm{Arg}+\mathrm{H}-\mathrm{H}_{2} \mathrm{O}\right]^{+}, 420\left[\mathrm{Ahp}+\mathrm{Phe}+\mathrm{MeTyr}+\mathrm{H}-\mathrm{H}_{2} \mathrm{O}\right]^{+}, 338[\mathrm{Arg}+\mathrm{Thr}+\mathrm{Val}$ $\left.+\mathrm{H}-\mathrm{H}_{2} \mathrm{O}\right]^{+}, 308[\mathrm{Phe}(-\mathrm{N})+\mathrm{MeTyr}+\mathrm{H}]^{+}, 297\left[\mathrm{Asp}+\mathrm{Thr}+\mathrm{Val}+\mathrm{H}-\mathrm{H}_{2} \mathrm{O}\right]^{+}, 243\left[\mathrm{Ahp}+\mathrm{Phe}+\mathrm{H}-\mathrm{H}_{2} \mathrm{O}\right]^{+}, 215$ $\left[\mathrm{Ahp}+\mathrm{Phe}+\mathrm{H}-\mathrm{H}_{2} \mathrm{O}-\mathrm{CO}\right]^{+}, 150$ MeTyr immonium ion, 120 Phe immonium ion, 70-Arg; Figure S6: Chemical structure (A) and product ion mass spectra of cyanopeptolin CP992 [Thr+Arg+Ahp+Phe+MeHty+Val]Asp+BA with precursor ion $[\mathrm{M}+\mathrm{H}]^{+}$at $m / z$ 993. The spectra were recorded with application of QTOF (B) and QTRAP (C) mass spectrometers. The mass signals were assigned to the following fragments: $975\left[\mathrm{M}+\mathrm{H}-\mathrm{H}_{2} \mathrm{O}\right]^{+}, 947$ $\left[\mathrm{M}+\mathrm{H}-\mathrm{H}_{2} \mathrm{O}-\mathrm{CO}\right]^{+}, 858\left[\mathrm{M}+\mathrm{H}-\mathrm{Val}--2 \mathrm{H}_{2} \mathrm{O}\right]^{+}, 808[\mathrm{M}+2 \mathrm{H}-(\mathrm{Asp}+\mathrm{BA})]^{+}, 790[\mathrm{M}+2 \mathrm{H}-(\mathrm{Asp}+$ BA $\left.)-\mathrm{H}_{2} \mathrm{O}\right]^{+}, 772\left[\mathrm{M}+2 \mathrm{H}-(\mathrm{Asp}+\mathrm{BA})-2 \mathrm{H}_{2} \mathrm{O}\right]^{+}, 673\left[\mathrm{M}+2 \mathrm{H}-\mathrm{Val}-(\mathrm{Asp}+\mathrm{BA})-2 \mathrm{H}_{2} \mathrm{O}\right]^{+}, 434[\mathrm{Ahp}$ + Phe + MeHty $+\mathrm{H}-\mathrm{H}_{2} \mathrm{O}^{+}, 425\left[\mathrm{BA}+\mathrm{Asp}+\mathrm{Thr}+\mathrm{Arg}+\mathrm{H}-\mathrm{H}_{2} \mathrm{O}\right]^{+}, 338\left[\mathrm{Arg}+\mathrm{Thr}+\mathrm{Val}+\mathrm{H}-\mathrm{H}_{2} \mathrm{O}\right]^{+}$, $322[\text { Phe }(-\mathrm{N})+\mathrm{MeHty}+\mathrm{H}]^{+}, 243\left[\mathrm{Ahp}+\mathrm{Ph}+\mathrm{H}-\mathrm{H}_{2} \mathrm{O}\right]^{+}, 215\left[\mathrm{Ahp}+\mathrm{Phe}+\mathrm{H}-\mathrm{H}_{2} \mathrm{O}-\mathrm{CO}\right]^{+}, 164 \mathrm{MeHty}$ immonium ion, 120 Phe immonium ion, 70-Arg; Figure S7: Chemical structure (A) and product ion mass spectra of cyanopeptolin CP990 [Thr+Arg+Ahp+Phe +MePhe+Val]Asp+HA with precursor ion $[\mathrm{M}+\mathrm{H}]^{+}$at $m / z 991$. The spectra were recorded with application of QTOF $(\mathbf{B})$ and QTRAP $(\mathbf{C})$ mass spectrometers. The mass signals were assigned to the following fragments: $973\left[\mathrm{M}+\mathrm{H}-\mathrm{H}_{2} \mathrm{O}\right]^{+}, 945\left[\mathrm{M}+\mathrm{H}-\mathrm{H}_{2} \mathrm{O}-\mathrm{CO}\right]^{+}, 856[\mathrm{M}+\mathrm{H}-\mathrm{Val}$ $\left.-2 \mathrm{H}_{2} \mathrm{O}\right]^{+}, 778[\mathrm{M}+2 \mathrm{H}-(\mathrm{Asp}+\mathrm{HA})]^{+}, 760\left[\mathrm{M}+2 \mathrm{H}-(\mathrm{Asp}+\mathrm{HA})-\mathrm{H}_{2} \mathrm{O}\right]^{+}, 750[\mathrm{M}+2 \mathrm{H}-(\mathrm{Asp}+\mathrm{HA})-$ $\mathrm{CO}]^{+}, 742\left[\mathrm{M}+2 \mathrm{H}-(\mathrm{Asp}+\mathrm{HA})-2 \mathrm{H}_{2} \mathrm{O}\right]^{+}, 643\left[\mathrm{M}+2 \mathrm{H}-\mathrm{Val}-(\mathrm{Asp}+\mathrm{HA})-2 \mathrm{H}_{2} \mathrm{O}\right]^{+}, 453[\mathrm{HA}+\mathrm{Asp}+\mathrm{Thr}+$ $\left.\mathrm{Arg}+\mathrm{H}-\mathrm{H}_{2} \mathrm{O}\right]^{+}, 404\left[\mathrm{Ahp}+\mathrm{Phe}+\mathrm{MePhe}+\mathrm{H}-\mathrm{H}_{2} \mathrm{O}\right]^{+}, 338\left[\mathrm{Arg}+\mathrm{Thr}+\mathrm{Val}+\mathrm{H}-\mathrm{H}_{2} \mathrm{O}\right]^{+}, 297[\mathrm{Asp}+\mathrm{Thr}+$ $\left.\mathrm{Val}+\mathrm{H}-\mathrm{H}_{2} \mathrm{O}\right]^{+}, 243\left[\mathrm{Ahp}+\mathrm{Phe}+\mathrm{H}_{-} \mathrm{H}_{2} \mathrm{O}\right]^{+}, 215\left[\mathrm{Ahp}+\mathrm{Phe}+\mathrm{H}-\mathrm{H}_{2} \mathrm{O}-\mathrm{CO}\right]^{+}, 134 \mathrm{MePhe}$ immonium ion, $120 \mathrm{Phe}$ immonium ion, 70-Arg; Figure S8: Chemical structure (A) and product ion mass spectra of cyanopeptolin CP978 $[\mathrm{Thr}+\mathrm{Arg}+\mathrm{Ahp}+\mathrm{Phe}+\mathrm{MeTyr}+\mathrm{Val}] \mathrm{Asp}+\mathrm{BA}$ with precursor ion $[\mathrm{M}+\mathrm{H}]^{+}$at $m / z 979$. The spectra were recorded with application of QTOF (B) and QTRAP (C) mass spectrometers. The mass signals were assigned to the following fragments: $961\left[\mathrm{M}+\mathrm{H}-\mathrm{H}_{2} \mathrm{O}\right]^{+}, 933\left[\mathrm{M}+\mathrm{H}-\mathrm{H}_{2} \mathrm{O}-\mathrm{CO}\right]^{+}, 844\left[\mathrm{M}+\mathrm{H}-\mathrm{Val}-2 \mathrm{H}_{2} \mathrm{O}\right]^{+}, 794[\mathrm{M}+2 \mathrm{H}-(\mathrm{Asp}+$ $\mathrm{BA})]^{+}, 776\left[\mathrm{M}+2 \mathrm{H}-(\mathrm{Asp}+\mathrm{BA})-\mathrm{H}_{2} \mathrm{O}\right]^{+}, 758\left[\mathrm{M}+2 \mathrm{H}-(\mathrm{Asp}+\mathrm{BA})-2 \mathrm{H}_{2} \mathrm{O}\right]^{+}, 659[\mathrm{M}+2 \mathrm{H}-\mathrm{Val}-(\mathrm{Asp}$ $\left.+\mathrm{BA})-2 \mathrm{H}_{2} \mathrm{O}\right]^{+}, 425\left[\mathrm{BA}+\mathrm{Asp}+\mathrm{Thr}+\mathrm{Arg}+\mathrm{H}-\mathrm{H}_{2} \mathrm{O}\right]^{+}, 420\left[\mathrm{Ahp}+\mathrm{Phe}+\mathrm{MeTyr}+\mathrm{H}-\mathrm{H}_{2} \mathrm{O}\right]^{+}, 338[\mathrm{Arg}$ $\left.+\mathrm{Thr}+\mathrm{Val}+\mathrm{H}-\mathrm{H}_{2} \mathrm{O}\right]^{+}, 308[\mathrm{Phe}(-\mathrm{N})+\mathrm{MeTyr}+\mathrm{H}]^{+}, 243\left[\mathrm{Ahp}+\mathrm{Phe}+\mathrm{H}-\mathrm{H}_{2} \mathrm{O}\right]^{+}, 215[$ Ahp $+\mathrm{Phe}+\mathrm{H}-$ $\left.\mathrm{H}_{2} \mathrm{O}-\mathrm{CO}\right]^{+}, 150$ MeTyr immonium ion, 120 Phe immonium ion, 70-Arg; Figure S9: Chemical structure (A) and product ion mass spectra of cyanopeptolin CP1027 [Thr+Tyr+Ahp+Phe+MeHty+Val]Asp+HA with precursor ion $\left[\mathrm{M}+\mathrm{H}-\mathrm{H}_{2} \mathrm{O}\right]^{+}$at $m / z$ 1010. The spectra were recorded with application of QTOF (B) and QTRAP (C) mass spectrometers. The mass signals were assigned to the following fragments: $992\left[\mathrm{M}+\mathrm{H}-2 \mathrm{H}_{2} \mathrm{O}\right]^{+}, 982[\mathrm{M}+\mathrm{H}-$ $\left.\mathrm{H}_{2} \mathrm{O}-\mathrm{CO}\right]^{+}, 964\left[\mathrm{M}+\mathrm{H}-2 \mathrm{H}_{2} \mathrm{O}-\mathrm{CO}^{+}, 911\left[\mathrm{M}+\mathrm{H}-\mathrm{Val}-\mathrm{H}_{2} \mathrm{O}\right]^{+}, 893\left[\mathrm{M}+\mathrm{H}-\mathrm{Val}-2 \mathrm{H}_{2} \mathrm{O}\right]^{+}, 819[\mathrm{M}+\mathrm{H}\right.$ $\left.-\mathrm{MeHty}-\mathrm{H}_{2} \mathrm{O}\right]^{+}, 797\left[\mathrm{M}+2 \mathrm{H}-(\mathrm{Asp}+\mathrm{HA})-\mathrm{H}_{2} \mathrm{O}\right]^{+}, 779\left[\mathrm{M}+2 \mathrm{H}-(\mathrm{Asp}+\mathrm{HA})-2 \mathrm{H}_{2} \mathrm{O}\right]^{+}, 751[\mathrm{M}+2 \mathrm{H}$ $\left.-(\mathrm{Asp}+\mathrm{HA})-2 \mathrm{H}_{2} \mathrm{O}-\mathrm{CO}\right]^{+}, 702\left[\mathrm{M}+\mathrm{H}-(\mathrm{Val}+\mathrm{MeHty})-\mathrm{H}_{2} \mathrm{O}\right]^{+}, 674\left[\mathrm{M}+\mathrm{H}-(\mathrm{Val}+\mathrm{MeHty})-\mathrm{H}_{2} \mathrm{O}-\right.$ $\mathrm{CO}^{+}, 460\left[\mathrm{M}+\mathrm{H}-(\mathrm{Val}+\mathrm{MeHty}+\mathrm{Phe}+\mathrm{Ahp})-\mathrm{H}_{2} \mathrm{O}\right]^{+}, 442\left[\mathrm{M}+\mathrm{H}-(\mathrm{Val}+\mathrm{MeHty}+\mathrm{Phe}+\mathrm{Ahp})-2 \mathrm{H}_{2} \mathrm{O}\right]^{+}$, $434\left[\text { Ahp }+ \text { Phe }+ \text { MeHty }+\mathrm{H}-\mathrm{H}_{2} \mathrm{O}\right]^{+}, 322[\mathrm{Phe}(-\mathrm{N})+\text { MeHty }+\mathrm{H}]^{+}, 297\left[\text { Asp }+\mathrm{Thr}+\mathrm{Val}+\mathrm{H}-\mathrm{H}_{2} \mathrm{O}\right]^{+}, 243$ $\left[\mathrm{Ahp}+\mathrm{Phe}+\mathrm{H}-\mathrm{H}_{2} \mathrm{O}\right]^{+}, 215\left[\mathrm{Ahp}+\mathrm{Phe}+\mathrm{H}-\mathrm{H}_{2} \mathrm{O}-\mathrm{CO}\right]^{+}, 164$ MeHty immonium ion, 136 Tyr immonium ion, 120 Phe immonium ion; Figure S10: Chemical structure (A) and product ion mass spectra of cyanopeptolin $\mathrm{CP} 1013[\mathrm{Thr}+\mathrm{Tyr}+\mathrm{Ahp}+\mathrm{Phe}+\mathrm{MeTyr}+\mathrm{Val}] \mathrm{Asp}+\mathrm{HA}$ with precursor ion $\left[\mathrm{M}+\mathrm{H}_{-} \mathrm{H}_{2} \mathrm{O}\right]^{+}$at $m / z$ 996. The spectra were recorded with application of QTOF $(\mathbf{B})$ and QTRAP $(\mathbf{C})$ mass spectrometers. The mass signals were assigned to the following fragments: $978\left[\mathrm{M}+\mathrm{H}-2 \mathrm{H}_{2} \mathrm{O}\right]^{+}, 968\left[\mathrm{M}+\mathrm{H}-\mathrm{H}_{2} \mathrm{O}-\mathrm{CO}\right]^{+}, 897\left[\mathrm{M}+\mathrm{H}-\mathrm{Val}-\mathrm{H}_{2} \mathrm{O}\right]^{+}, 879[\mathrm{M}+$ $\left.\mathrm{H}-\mathrm{Val}-2 \mathrm{H}_{2} \mathrm{O}\right]^{+}, 819\left[\mathrm{M}+\mathrm{H}-\mathrm{MeTyr}-\mathrm{H}_{2} \mathrm{O}\right]^{+}, 783\left[\mathrm{M}+2 \mathrm{H}-(\mathrm{Asp}+\mathrm{HA})-\mathrm{H}_{2} \mathrm{O}\right]^{+}, 765[\mathrm{M}+2 \mathrm{H}-(\mathrm{Asp}+$ $\left.\mathrm{HA})-2 \mathrm{H}_{2} \mathrm{O}\right]^{+}, 736\left[\mathrm{M}+\mathrm{H}-(\mathrm{Asp}+\mathrm{HA})-2 \mathrm{H}_{2} \mathrm{O}-\mathrm{CO}^{+}, 720\left[\mathrm{M}+\mathrm{H}-(\mathrm{Val}+\mathrm{MeTyr})-\mathrm{H}_{2} \mathrm{O}\right]^{+}, 702[\mathrm{M}+\mathrm{H}-\right.$ $\left.(\mathrm{Val}+\mathrm{MeTyr})-2 \mathrm{H}_{2} \mathrm{O}\right]^{+}, 666\left[\mathrm{M}+2 \mathrm{H}-\mathrm{Val}-(\mathrm{Asp}+\mathrm{HA})-2 \mathrm{H}_{2} \mathrm{O}\right]^{+}, 460[\mathrm{M}+\mathrm{H}-(\mathrm{Val}+\mathrm{MeTyr}+\mathrm{Phe}+\mathrm{Ahp})-$ $\left.\mathrm{H}_{2} \mathrm{O}\right]^{+}, 420\left[\mathrm{Ahp}+\mathrm{Phe}+\mathrm{MeTyr}+\mathrm{H}-\mathrm{H}_{2} \mathrm{O}\right]^{+}, 432\left[\mathrm{M}+\mathrm{H}-(\mathrm{Val}+\mathrm{MeTyr}+\mathrm{Phe}+\mathrm{Ahp})-\mathrm{H}_{2} \mathrm{O}-\mathrm{CO}\right]^{+}, 414[\mathrm{HA}$ $+\mathrm{Asp}+\mathrm{Thr}+\mathrm{Val}+\mathrm{H}]^{+}, 297\left[\mathrm{Asp}+\mathrm{Thr}+\mathrm{Val}+\mathrm{H}-\mathrm{H}_{2} \mathrm{O}\right]^{+}, 243\left[\mathrm{Ahp}+\mathrm{Phe}+\mathrm{H}-\mathrm{H}_{2} \mathrm{O}\right]^{+}, 215[\mathrm{Ahp}+\mathrm{Phe}+\mathrm{H}-$ $\mathrm{H}_{2} \mathrm{O}-\mathrm{CO}^{+}, 150$ MeTyr immonium ion, 136 Tyr immonium ion, 120 Phe immonium ion; Figure S11. Chemical structure (A) and product ion mass spectra of cyanopeptolin CP999 [Thr+Tyr+Ahp+Phe+MeHty+Val]Asp+BA with precursor ion $\left[\mathrm{M}+\mathrm{H}-\mathrm{H}_{2} \mathrm{O}\right]^{+}$at $m / z$ 982. The spectra were recorded with application of QTOF (B) and QTRAP (C) mass spectrometers. The mass signals were assigned to the following fragments: $964\left[\mathrm{M}+\mathrm{H}-2 \mathrm{H}_{2} \mathrm{O}\right]^{+}, 954$ $\left[\mathrm{M}+\mathrm{H}-\mathrm{H}_{2} \mathrm{O}-\mathrm{CO}\right]^{+}, 883\left[\mathrm{M}+\mathrm{H}-\mathrm{Val}-\mathrm{H}_{2} \mathrm{O}\right]^{+}, 865\left[\mathrm{M}+\mathrm{H}-\mathrm{Val}-2 \mathrm{H}_{2} \mathrm{O}\right]^{+}, 797[\mathrm{M}+2 \mathrm{H}-(\mathrm{Asp}+\mathrm{BA})-$ $\mathrm{H}_{2} \mathrm{O}^{+}, 779\left[\mathrm{M}+2 \mathrm{H}-(\mathrm{Asp}+\mathrm{BA})-2 \mathrm{H}_{2} \mathrm{O}\right]^{+}, 751\left[\mathrm{M}+2 \mathrm{H}-(\mathrm{Asp}+\mathrm{BA})-2 \mathrm{H}_{2} \mathrm{O}-\mathrm{CO}^{+}, 692[\mathrm{M}+\mathrm{H}-(\mathrm{Val}+\right.$ MeHty $\left.)-\mathrm{H}_{2} \mathrm{O}\right]^{+}, 674\left[\mathrm{M}+\mathrm{H}-(\mathrm{Val}+\mathrm{MeHty})-2 \mathrm{H}_{2} \mathrm{O}\right]^{+}, 698\left[\mathrm{M}+2 \mathrm{H}-\mathrm{Val}-(\mathrm{Asp}+\mathrm{BA})-\mathrm{H}_{2} \mathrm{O}\right]^{+}, 680[\mathrm{M}+$ $2 \mathrm{H}-\mathrm{Val}-(\mathrm{Asp}+\mathrm{BA})-2 \mathrm{H}_{2} \mathrm{O}^{+}, 646\left[\mathrm{M}+\mathrm{H}-(\mathrm{Val}+\mathrm{MeHty})-2 \mathrm{H}_{2} \mathrm{O}-\mathrm{CO}^{+}, 434[\mathrm{Ahp}+\mathrm{Phe}+\mathrm{MeHty}+\mathrm{H}\right.$ $\left.-\mathrm{H}_{2} \mathrm{O}\right]^{+}, 432\left[\mathrm{M}+\mathrm{H}-(\mathrm{Val}+\mathrm{MeHty}+\mathrm{Phe}+\mathrm{Ahp})-\mathrm{H}_{2} \mathrm{O}\right]^{+}, 386[\mathrm{BA}+\mathrm{Asp}+\mathrm{Thr}+\mathrm{Val}+\mathrm{H}]^{+}, 322[\mathrm{Phe}(-\mathrm{N})+$ $\mathrm{MeHty}+\mathrm{H}]^{+}, 269\left[\mathrm{Asp}+\mathrm{Thr}+\mathrm{Val}+\mathrm{H}-\mathrm{H}_{2} \mathrm{O}-\mathrm{CO}\right]^{+}, 243\left[\mathrm{Ahp}+\mathrm{Phe}+\mathrm{H}-\mathrm{H}_{2} \mathrm{O}\right]^{+}, 215[\mathrm{Ahp}+\mathrm{Phe}+\mathrm{H}-$ $\left.\mathrm{H}_{2} \mathrm{O}-\mathrm{CO}\right]^{+}, 164 \mathrm{MeHty}$ immonium ion, $136 \mathrm{Tyr}$ immonium ion, 120 Phe immonium ion; Figure S12. Chemical structure (A) and product ion mass spectra of cyanopeptolin CP969 [Thr+Tyr+Ahp+Phe+MePhe+Val]Asp+BA with precursor ion $\left[\mathrm{M}+\mathrm{H}-\mathrm{H}_{2} \mathrm{O}\right]^{+}$at $m / z$ 952. The spectra were recorded with application of QTOF (B) and QTRAP (C) mass spectrometers. The mass signals were assigned to the following fragments: 934 [M $+\mathrm{H}-$ $\left.2 \mathrm{H}_{2} \mathrm{O}\right]^{+}, 924\left[\mathrm{M}+\mathrm{H}-\mathrm{H}_{2} \mathrm{O}-\mathrm{CO}\right]^{+}, 853\left[\mathrm{M}+\mathrm{H}-\mathrm{Val}-\mathrm{H}_{2} \mathrm{O}\right]^{+}, 835\left[\mathrm{M}+\mathrm{H}-\mathrm{Val}-2 \mathrm{H}_{2} \mathrm{O}\right]^{+}, 791[\mathrm{M}+\mathrm{H}-$ 
MePhe $\left.-\mathrm{H}_{2} \mathrm{O}\right]^{+}, 767\left[\mathrm{M}+2 \mathrm{H}-(\mathrm{Asp}+\mathrm{BA})-\mathrm{H}_{2} \mathrm{O}\right]^{+}, 749\left[\mathrm{M}+2 \mathrm{H}-(\mathrm{Asp}+\mathrm{BA})-2 \mathrm{H}_{2} \mathrm{O}\right]^{+}, 692[\mathrm{M}+\mathrm{H}-$ $\left.(\mathrm{Val}+\mathrm{MePhe})-\mathrm{H}_{2} \mathrm{O}\right]^{+}, 674\left[\mathrm{M}+\mathrm{H}-(\mathrm{Val}+\mathrm{MePhe})-2 \mathrm{H}_{2} \mathrm{O}\right]^{+}, 432[\mathrm{M}+\mathrm{H}-(\mathrm{Val}+\mathrm{MePhe}+\mathrm{Phe}+\mathrm{Ahp})-$ $\mathrm{H}_{2} \mathrm{O}^{+}, 414\left[\mathrm{M}+\mathrm{H}-(\mathrm{Val}+\mathrm{MePhe}+\mathrm{Phe}+\mathrm{Ahp})-2 \mathrm{H}_{2} \mathrm{O}\right]^{+}, 404\left[\mathrm{Ahp}+\mathrm{Phe}+\mathrm{MePhe}+\mathrm{H}-\mathrm{H}_{2} \mathrm{O}\right]^{+}, 386[\mathrm{BA}+$ Asp $+\mathrm{Thr}+\mathrm{Val}+\mathrm{H}]^{+}, 297\left[\mathrm{Asp}+\mathrm{Thr}+\mathrm{Val}+\mathrm{H}-\mathrm{H}_{2} \mathrm{O}^{+}, 243\left[\mathrm{Ahp}+\mathrm{Phe}+\mathrm{H}-\mathrm{H}_{2} \mathrm{O}\right]^{+}, 215[\right.$ Ahp $+\mathrm{Phe}+\mathrm{H}-$ $\left.\mathrm{H}_{2} \mathrm{O}-\mathrm{CO}\right]^{+}, 134 \mathrm{MePhe}$ immonium ion, $136 \mathrm{Tyr}$ immonium ion, 120 Phe immonium ion; Figure S13. ${ }^{1} \mathrm{H}-\mathrm{NMR}$ Spectrum of cyanopeptolin CP985 in DMSO-d $\mathrm{d}_{6}$; Figure S14. HSQC Spectrum of cyanopeptolin CP985 in DMSO- $\mathrm{d}_{6}$; Figure S15a. HMBC Spectrum of cyanopeptolin CP985 in DMSO-d ${ }_{6}$; Figure S15b. Detailed NH $-\mathrm{C}=\mathrm{O}$ region of the HMBC spectrum of cyanopeptolin CP985; Figure S15c. Detailed aromatic region of the HMBC spectrum of cyanopeptolin CP985; Figure S16. COSY Spectrum of cyanopeptolin CP985 in DMSO- $\mathrm{d}_{6}$; Figure S17a. TOCSY Spectrum of cyanopeptolin CP985 in DMSO- $\mathrm{d}_{6}$; Figure $\mathrm{S17b}$. Amino acid spin systems in the diagnostic region of the TOCSY spectrum of cyanopeptolin CP985; Figure S18a. ROESY Spectrum of cyanopeptolin CP985 in DMSO-d 6 ; Figure S18b. Overlaid fragments of TOCSY (green) and ROESY (red) spectra of cyanopeptolin CP985; Figure S19. ${ }^{1} \mathrm{H}-\mathrm{NMR}$ Spectrum of cyanopeptolin CP962 in DMSO-d $\mathrm{d}_{6}$; Figure S20. HSQC Spectrum of cyanopeptolin CP962 in DMSO- $\mathrm{d}_{6}$; Figure S21a. HMBC Spectrum of cyanopeptolin CP962 in DMSO- $\mathrm{d}_{6}$; Figure S21b. Detailed NH-C=O region of the HMBC spectrum of cyanopeptolin CP962; Figure S21c. Detailed aromatic region of the HMBC spectrum of cyanopeptolin CP962; Figure S22. COSY Spectrum of cyanopeptolin CP962 in DMSO-d 6 ; Figure S23a. TOCSY Spectrum of cyanopeptolin CP962 in DMSO- $\mathrm{d}_{6}$; Figure S23b. Amino acid spin systems in the diagnostic region of the TOCSY spectrum of cyanopeptolin CP962; Figure S24a. ROESY Spectrum of cyanopeptolin CP962 in DMSO- $\mathrm{d}_{6}$; Figure S24b. Overlaid fragments of TOCSY (green) and ROESY (red) spectra of cyanopeptolin CP962.

Author Contributions: H.M.-M. and C.E. designed the study and performed the extraction, fractionation, and isolation of CPs. H.M.-M., C.E., A.F., and M.C. participated in LC-MS/MS analyses, and in acquisition and interpretation of data and manuscript preparation. A.F. and M.C. performed the enzyme inhibition assays; M.G. and J.M. performed MTT assay. NMR analyses were done by E.W. and M.K. All authors discussed the results and contributed to the work on the manuscript.

Acknowledgments: The work was supported by the National Science Centre in Poland 2016/21/B/NZ9/02304 to Hanna Mazur-Marzec and 2014/15/B/NZ7/01014 to Elżbieta Jankowska. COST action ES1105 "CYANOCOST-Cyanobacterial blooms and toxins in water resources: Occurrence, impacts and management" is acknowledged for adding value to this study through networking and knowledge sharing with European experts.

Conflicts of Interest: The authors declare no conflicts of interest.

\section{References}

1. Moore, R.E. Cyclic peptides and depsipeptides from cyanobacteria: A review. J. Ind. Microbiol. 1996, 16, 134-143. [CrossRef] [PubMed]

2. Gerwick, L.; Gerwick, W.H.; Coates, R.C.; Engene, N.; Grindberg, R.V.; Jones, A.C.; Sorrels, C.M. Giant marine cyanobacteria produce exciting potential pharmaceuticals. Microbe 2008, 3, 277-284. [CrossRef]

3. Nagarajan, M.; Maruthanayagam, V.; Sundararaman, M. A review of pharmacological and toxicological potentials of marine cyanobacterial metabolites. J. Appl. Toxicol. 2011, 33, 153-185. [CrossRef] [PubMed]

4. Sainis, I.; Fokas, D.; Vareli, K.; Tzakos, A.G.; Kounnis, V.; Briasoulis, E. Cyanobacterial cyclopeptides as lead compounds to novel targeted cancer drugs. Mar. Drugs 2010, 8, 629-657. [CrossRef] [PubMed]

5. Costa, M.; Costa-Rodrigues, J.; Fernandes, M.H.; Barros, P.; Vasconcelos, V.; Martins, R. Marine cyanobacteria compounds with anticancer properties: A Review on the implication of apoptosis. Mar. Drugs 2012, 10, 2181-2207. [CrossRef] [PubMed]

6. Hong, J.; Luesch, H. Largazole: From discovery to broad-spectrum therapy. Nat. Prod. Rep. 2012, $29,449-456$. [CrossRef] [PubMed]

7. Salvador-Reyes, L.A.; Luesch, H. Biological targets and mechanisms of action of natural products from marine cyanobacteria. Nat. Prod. Rep. 2015, 32, 478-503. [CrossRef] [PubMed]

8. Ersmark, K.; Del Valle, J.R.; Hanessian, S. Chemistry and biology of the aeruginosin family of serine protease inhibitors. Angew. Chem. Int. Ed. Engl. 2008, 47, 1202-1223. [CrossRef] [PubMed]

9. Chlipala, G.; Mo, S.; Orjala, J. Chemodiversity in freshwater and terrestrial cyanobacteria-A source for drug discovery. Curr. Drug Targets 2011, 12, 1654-1673. [CrossRef] [PubMed]

10. Elkobi-Peer, S.; Carmeli, S. New prenylated aeruginosin, microphycin, anabaenopeptin and micropeptin analogues from microcystis bloom material collected in Kibbutz Kfar Blum, Israel. Mar. drugs 2015, 13, 2347-2375. [CrossRef] [PubMed]

11. Itou, Y.; Ishida, K.; Shin, H.; Murakami, M. Oscillapeptins A to F, serine protease inhibitors from the three strains of Oscillatoria agardhii. Tetrahedron 1999, 55, 6871-6882. [CrossRef] 
12. Gesner-Apter, S.; Carmeli, S. Protease inhibitors from a water bloom of the cyanobacterium Microcystis aeruginosa. J. Nat. Prod. 2009, 72, 1429-1436. [CrossRef] [PubMed]

13. Welker, M.; von Döhren, H. Cyanobacterial peptides-Nature's own combinatorial biosynthesis. FEMS Microbiol. Rev. 2006, 30, 530-563. [CrossRef] [PubMed]

14. Cadel-Six, S.; Dauga, C.; Castests, A.; Rippka, R.; Bouchier, C.; Tandeau de Marsac, N.; Welker, M. Halogenase genes in nonribosomal peptide synthetase gene clusters of Microcystis (Cyanobacteria): Sporadic distribution and evolution. Mol. Biol. Evol. 2008, 25, 2031-2041. [CrossRef] [PubMed]

15. Martin, C.; Oberer, L.; Ino, T.; König, W.; Busch, M.; Weckesser, J. Cyanopeptolins, new depsipeptides from the cyanobacterium Microcystis sp. PCC 7806. J. Antibiot. 1993, 46, 1550-1556. [CrossRef] [PubMed]

16. Czarnecki, O.; Henning, M.; Lippert, I.; Welker, M. Identification of peptide metabolites of Microcystis (Cyanobacteria) that inhibit trypsin-like activity in planktonic herbivorous Daphnia (Cladocera). Environ. Microbiol. 2006, 8, 77-87. [CrossRef] [PubMed]

17. Welker, M.; Brunke, M.; Preussel, K.; Lippert, I.; von Döhren, H. Diversity and distribution of Microcystis (Cyanobacteria) oligopeptide chemotypes from natural communities studied by single-colony mass spectrometry. Microbiology 2004, 150, 1785-1796. [CrossRef] [PubMed]

18. Jakobi, C.; Rinehart, K.; Neuber, R.; Mez, K.; Weckesser, J. Cyanopeptolin SS, a disulphated depsipeptide from a water bloom: Structural elucidation and biological activities. Phycologia 1996, 35, 111-116. [CrossRef]

19. Tsukamoto, S.; Painuly, P.; Young, K.; Yang, X.; Shimizu, Y. Microcystilide A: A novel cell-differentiationpromoting depsipeptide from Microcystis aeruginosa NO-15-1840. J. Am. Chem. Soc. 1993, 115, 11046-11047. [CrossRef]

20. Harada, K.; Mayumi, T.; Shimada, T.; Fuji, K.; Kondo, F.; Park, H.; Watanabe, M. Co-production of microcystins and aeruginopeptins by natural cyanobacterial bloom. Environ. Toxicol. 2001, 16, 298-305. [CrossRef] [PubMed]

21. Adiv, S.; Aharonv-Nadborny, R.; Carmeli, S. Micropeptins from Microcystis aeruginosa collected in Dalton reservoir, Israel. Tetrahedron 2010, 66, 7429-7436. [CrossRef]

22. Rounge, T.; Rohrlack, T.; Tooming-Klunderud, A.; Kristensen, T.; Jakobsen, K. Comparison of cyanopeptolin genes in Planktothrix, Microcystis and Anabaena strains: Evidence for independent evolution within each genus. Appl. Environ. Microbiol. 2007, 73, 7322-7330. [CrossRef] [PubMed]

23. Tooming-Klunderud, A.; Rohrlack, T.; Shalchian-Tabrizi, K.; Kristensen, T.; Jakobsen, K. Structural analysis of non-ribosomal halogenated cyclic peptide and its putative operon from Microcystis: Implications for evolution of cyanopeptolins. Microbiol. 2007, 153, 1382-1393. [CrossRef] [PubMed]

24. Rouhiainen, L.; Paulin, L.; Suomalainen, S.; Hyytiäinen, H.; Buikema, W.; Haselkorn, R.; Sivonen, K. Genes encoding synthetases of cyclic depsipeptides, anabaenopeptilides, in Anabaena strain 90. Mol. Microbiol. 2000, 37, 156-167. [CrossRef] [PubMed]

25. Weckesser, J.; Martin, C.; Jakobi, C. Cyanopeptolins, depsipeptides from cyanobacteria. System. Appl. Microbiol. 1996, 19, 133-138. [CrossRef]

26. Namikoshi, M.; Rinehart, K. Bioactive compounds produced by cyanobacteria. J. Ind. Microbiol. Biotechnol. 1996, 17, 373-384. [CrossRef]

27. Bister, B.; Keller, S.; Baumann, H.; Nicholson, G.; Weist, S.; Jung, G.; Süssmuth, R.; Jüttner, F. Cyanopeptolin 963 A, a chymotrypsin inhibitor of Microcystis PCC 7806. J. Nat. Prod. 2004, 67, 1755-1757. [CrossRef] [PubMed]

28. Yamaki, H.; Sitachitta, N.; Sano, T.; Kaya, K. Two new chymotrypsin inhibitors isolated from the cyanobacterium Microcystis aeruginosa NIES-88. J. Nat. Prod. 2005, 68, 14-18. [CrossRef] [PubMed]

29. Linington, R.; Edwards, D.; Shuman, C.; McPhail, K.; Matainaho, T.; Gerwick, W. Symplocamide A, a potent cytotoxin and chymotrypsin inhibitor from the marine cyanobacterium Symploca sp. J. Nat. Prod. 2008, 71, 22-27. [CrossRef] [PubMed]

30. Okumura, H.; Philmus, B.; Portmann, C.; Hemscheidt, T. Homotyrosine-containing cyanopeptolins 880 \& 960 and anabaenopeptins 908 \& 915 from Planktothrix agardhii CYA 126/8. J. Nat. Prod. 2009, 72, 172-176. [CrossRef] [PubMed]

31. Zainuddin, E.; Mentel, R.; Wray, V.; Jansen, R.; Nimtz, M.; Lalk, M.; Mundt, S. Cyclic depsipeptides, ichthyopeptins A and B, from Microcystis ichthyoblabe. J. Nat. Prod. 2007, 70, 1084-1088. [CrossRef] [PubMed] 
32. Gademann, K.; Portmann, C.; Blom, J.; Zeder, M.; Jüttner, F. Multiple toxin production in the cyanobacterium Microcystis: Isolation of the toxic protease inhibitor cyanopeptolin 1020. J. Nat. Prod. 2010, 73, 980-984. [CrossRef] [PubMed]

33. Blom, J.; Bister, B.; Bischoff, D.; Nicholson, G.; Jung, G.; Süssmuth, R.; Jüttner, F. Oscillapeptin J, a new grazer toxin of the freshwater cyanobacterium Planktothrix rubescens. J. Nat. Prod. 2003, 66, 431-434. [CrossRef] [PubMed]

34. Kaya, K.; Sano, T.; Beattie, K.; Codd, G. Nostocyclin, a novel 3-amino-6-hydroxy-2-piperidone-containing cyclic depsipeptide from the cyanobacterium Nostoc sp. Tetrahedron Lett. 1996, 37, 6725-6728. [CrossRef]

35. Okino, T.; Qi, S.; Matsua, H.; Murakami, M.; Yamaguchi, K. Nostopeptins A and B, elastase inhibitors from the cyanobacterium Nostoc minutum. J. Nat. Prod. 1997, 60, 158-161. [CrossRef]

36. Ploutno, A.; Carmeli, S. Modified peptides from a water bloom of the cyanobacterium Nostoc sp. Tetrahedron 2002, 58, 9949-9957. [CrossRef]

37. Dembitsky, V.; Řezanka, T. Metabolites produced by nitrogen-fixing Nostoc species. Folia Microbiol. 2005, 50, 363-391. [CrossRef]

38. Mehner, C.; Müller, D.; Kehraus, S.; Hautmann, S.; Gütschow, M.; König, G. New peptolides from the cyanobacterium Nostoc insulare as selective and potent inhibitors of human leukocyte elastase. ChemBioChem 2008, 9, 2692-2703. [CrossRef] [PubMed]

39. Hastie, J.; Borthwick, E.; Morrison, L.; Codd, G.; Cohen, P. Inhibition of several protein phosphatases by a non-covalently interacting microcystin and a novel cyanobacterial peptide, nostocyclin. BBA 2005, 1726, 187-193. [CrossRef] [PubMed]

40. Piccardi, R.; Frosini, A.; Tredici, M.; Margheri, M. Bioactivity in free-living and symbiotic cyanobacteria of the genus Nostoc. J. Appl. Phycol. 2000, 12, 543-547. [CrossRef]

41. Ploutno, A.; Carmeli, S. Banyasin A and banyasides A and B, three novel modified peptides from water bloom of the cyanobacterium Nostoc sp. Tetrahedron 2005, 61, 575-583. [CrossRef]

42. Tidgewell, K.; Clark, B.; Gerwick, W. The Natural Products Chemistry of Cyanobacteria; University of California San Diego: La Jolla, CA, USA, 2010; pp. 142-187.

43. Liu, L.; Jokela, J.; Herfindal, L.; Wahlsten, M.; Sinkkonen, J.; Permi, P.; Fewer, D.; Ove Døskeland, S.; Sivonen, K. 4-methylproline guided natural product discovery: Co-occurrence of 4-hydroxy- and 4-methylprolines in nostoweipeptins and nostopeptolides. ACS Chem. Biol. 2014, 9, 2646-2655. [CrossRef] [PubMed]

44. Trimurtulu, G.; Patterson, G.; Corbett, T.; Ohtani, I.; Moore, R.; Valeriote, F. Total structures of cryptophycins, potent antitumor depsipeptides from the blue-green alga Nostoc sp. GSV 224. J. Am. Chem. Soc. 1994, 116, 4729-4737. [CrossRef]

45. Weiss, C.; Figueras, E.; Borbely, A.; Sewald, N. Cryptophycins: Cytotoxic cyclodepsipeptides with potential for tumor targeting. J. Pept. Sci. 2017, 23, 514-531. [CrossRef] [PubMed]

46. Dey, B.; Lerner, D.; Lusso, P.; Boyd, M.; Elder, J.; Berger, E. Multiple antiviral activities of cyanovirin-N: Blocking of human immunodeficiency virus type 1 gp120 interaction with CD4 and coreceptor and inhibition of diverse enveloped viruses. J. Virol. 2000, 74, 4562-4569. [CrossRef] [PubMed]

47. Mayumi, T.; Kato, H.; Kawasaki, Y.; Harada, K. Formation of diagnostic product ions from cyanobacterial cyclic peptides by the two-bond fission mechanism using ion trap liquid chromatography/multi-stage mass spectrometry. Rapid Commun. Mass Spectrom. 2007, 21, 1025-1033. [CrossRef] [PubMed]

48. Welker, M.; Christiansen, G.; von Döhren, H. Diversity of coexisting Planktothrix (Cyanobacteria) chemotypes deduced by mass spectral analysis of microcystins and other oligopeptides. Arch. Microbiol. 2004, 182, 288-298. [CrossRef] [PubMed]

49. Choi, H.; Oh, S.; Yih, W.; Chin, J.; Kang, H.; Rho, J. Cyanopeptoline CB071: A cyclic depsipeptide isolated from the freshwater cyanobacterium Aphanocapsa sp. Chem. Pharm. Bull. 2008, 56, 1191-1193. [CrossRef] [PubMed]

50. Okano, T.; Sano, T.; Kaya, K. Micropeptin T-20, a novel phosphate-containing cyclic depsipeptide from the cyanobacterium Microcystis aeruginosa. Tetraherdon Lett. 1999, 40, 2379-2382. [CrossRef]

51. Srikanth, S.; Chen, Z. Plant protease inhibitors in therapeutics-focus on cancer therapy. Front. Pharmacol. 2016, 7, 1-19. [CrossRef] [PubMed]

52. Blom, J.; Baumann, H.; Codd, G.; Jüttner, F. Sensitivity and adaptation of aquatic organisms to oscillapeptin J and [D-Asp ${ }^{3},(E)-\mathrm{Dhb}^{7}$ ] microcystin-RR. Arch. Hydrobiol. 2006, 167, 547-559. [CrossRef] 
53. Faltermann, S.; Hutter, S.; Christen, V.; Hettich, T.; Fent, K. Anti-inflammatory activity of cyanobacterial serine protease inhibitors aeruginosin 828A and cyanopeptolin 1020 in human hepatoma cell line Huh7 and effects in Zebrafish (Danio rerio). Toxins 2016, 8, 219. [CrossRef] [PubMed]

54. Faltermann, S.; Zucchi, S.; Kohler, E.; Blom, J.; Pernthaler, J.; Fent, K. Molecular effects of the cyanobacterial toxin cyanopeptolin (CP1020) occurring in algal blooms: Global transcriptome analysis in zebrafish embryos. Aquat. Toxicol. 2014, 149, 33-39. [CrossRef] [PubMed]

55. Kotai, J. Introduction for Preparation of Modified Nutrient Solution Z8 for Algae; Norwegian Institute for Water Research Publication B-117669: Oslo, Norway, 1972; 5p.

56. Ocampo Bennet, X. Peptide au Seiner Cyanobakterien Wasserblütte (1998) aus dem Wannsee/Berli: Strukturen and Biologische Wirksamkeit; University of Freiburg: Freiburg, Germany, 2007; 28p.

57. Kwan, J.; Taori, K.; Paul, V.; Luesch, H. Lyngbyastatins 8-10, elastase inhibitors with cyclic depsipeptide scaffolds isolated from the marine cyanobacterium Lyngbya semiplena. Mar. Drugs 2009, 7, 528-538. [CrossRef] [PubMed]

58. Rapala, J.; Erkomaa, K.; Kukkonen, J.; Sivonen, K.; Lahti, K. Detection of microcystins with protein phosphatase inhibition assay, high-performance liquid chromatography-UV detection and enzyme-linked immunosorbent assay. Comparison of methods. Anal. Chim. Acta 2002, 466, 213-231. [CrossRef]

(C) 2018 by the authors. Licensee MDPI, Basel, Switzerland. This article is an open access article distributed under the terms and conditions of the Creative Commons Attribution (CC BY) license (http:/ / creativecommons.org/licenses/by/4.0/). 